\title{
Mental depression: Relation to different disease status, newer treatments and its association with COVID-19 pandemic (Review)
}

\author{
MOHAMED S. ABDEL-BAKKY ${ }^{1,2}$, ELHAM AMIN ${ }^{3,4}$ \\ TAREK M. FARIS ${ }^{5}$ and AHMED A.H. ABDELLATIF ${ }^{6,7}$
}

\begin{abstract}
${ }^{1}$ Department of Pharmacology and Toxicology, College of Pharmacy, Qassim University, Buraydah, Qassim 51452, Saudi Arabia;
${ }^{2}$ Department of Pharmacology and Toxicology, Faculty of Pharmacy (Boys), Al-Azhar University, Cairo 11884;

${ }^{3}$ Department of Pharmacognosy, Faculty of Pharmacy, Beni-Suef University, Beni-Suef 62514, Egypt;

${ }^{4}$ Department of Medicinal Chemistry and Pharmacognosy, College of Pharmacy, Qassim University, Buraydah, Qassim 52471, Saudi Arabia; ${ }^{5}$ Department of Pharmaceutics and Industrial Pharmacy, College of Pharmacy, Al-Azhar University, Cairo 11884, Egypt; ${ }^{6}$ Department of Pharmaceutics, College of Pharmacy, Qassim University, Buraydah, Qassim 51452, Saudi Arabia; ${ }^{7}$ Department of Pharmaceutics and Industrial Pharmacy, Faculty of Pharmacy, Al-Azhar University, Assiut 71524, Egypt
\end{abstract}

Received June 1, 2020; Accepted September 10, 2021

DOI: $10.3892 / \mathrm{mmr} .2021 .12479$

\begin{abstract}
The present study aimed to review major depression, including its types, epidemiology, association with different diseases status and treatments, as well as its correlation with the current COVID-19 pandemic. Mental depression is a common disorder that affects most individuals at one time or another. During depression, there are changes in mood and behavior, accompanied by feelings of defeat, hopelessness, or even suicidal thoughts. Depression has a direct or indirect relation with a number of other diseases including Alzheimer's disease, stroke, epilepsy, diabetes, cardiovascular disease and cancer. In addition, antidepressant drugs have several side effects including sedation, increased weight, indigestion, sexual dysfunction, or a decrease in blood pressure. Stopping medication may cause a relapse of the symptoms of depression and pose a risk of attempted suicide. The pandemic of COVID-19 has affected the mental health of individuals, including patients, individuals contacting patients and medical staff with a number of mental disorders that may adversely affect the immune ability of their bodies. Some of the drugs currently included in the protocols for treating COVID-19 may negatively affect the mental health of patients. Evidence accumulated over the years indicates that serotonin (5HT) deficiencies and norepinephrine (NE) in the
\end{abstract}

Correspondence to: Dr Ahmed A.H. Abdellatif, Department of Pharmaceutics, College of Pharmacy, Qassim University, A2 Almelida Street, Buraydah, Qassim 51452, Saudi Arabia

E-mail: a.abdellatif@qu.edu.sa

Key words: major depression, neurotransmitters, molecular mechanism, COVID-19, latest treatments, mental health brain can lead to mental depression. Drugs that increase levels of NE and 5HT are commonly used in the treatment of depression. The common reason for mood disorders, including mania and bipolar disease are not clearly understood. It is assumed that hyperactivity in specific parts of the brain and excessive activity of neurotransmitters may be involved. Early diagnosis and developing new treatment strategies are essential for the prevention of the severe consequences of depression. In addition, extensive research should be directed towards the investigation of the mental health disturbances occurring during and/or after COVID-19 infection. This may lead to the incorporation of a suitable antidepressant into the current treatment protocols.

\section{Contents}

1. Introduction

2. Epidemiology

3. Biological markers and clinical presentation of depression

4. Depression and common medical diseases

5. Depression and the metabolic diseases

6. Depression and endocrine disorders

7. Depression and cardiovascular diseases

8. Depression and inflammatory status

9. Depression and daylight

10. Depression in the deficiency state

11. Depression and glutamate

12. Depression in neurodegenerative cases

13. Depression and oxidative stress

14. Gene expression in depression

15. Treatment of depression

16. COVID-19 and depression

17. Depression and cytokine storm in COVID-19

18. Summary 


\section{Introduction}

Mental depression is a common psychiatric disorder, where 264 million individuals of different ages suffered from depressive behavior at January 2020 with $~ 800,000$ annual suicides (World Health Organization, WHO) (1). Although depression has been extensively studied, its mechanisms remain to be elucidated. Norepinephrine and serotonin are two neurotransmitters considered to be the most efficient in mental depression (2). The areas in the brain supposed to be affected include the temporal and frontal lobes and the cingulate gyrus of the limbic system (Fig. 1) (3). The symptoms of depression are mostly mild and unpredicted either by patients or even physicians. The typical types of depression, whether major or minor, have only symptoms of depression (4). However, bipolar and cyclothymic types are accompanied by manic symptoms (5). According to the American Psychiatric Associations of the Diagnostic and Statistical Manual of Mental Disorders (DSM-5), depressive disorders are classified into three common types based on a theoretical basis; the first type usually occurs due to stressful stimuli. The second type is genetically based and termed endogenous depression; it is demonstrated through patient difficulties in dealing with normal life (6). The third type is bipolar depression (or manicdepressive disorder).

By contrast, the International Alliance on Mental Illness classifies depression into nine common types; Major Depression: patients with this type feel excessive sadness, lack of energy, irritability, hopelessness, physical pain, lower concentration, alterations in eating or sleep habits, feelings of guilt and attempted suicide. Only two weeks of suffering these symptoms are needed to officially diagnose major depression (7). Dysthymia is a type of depression that causes persistent low mood with changes in sleep habits, sadness, trouble in concentration, fatigue and appetite loss. Talk therapy, not medication, is usually suitable for this type of depression (8). Postpartum depression (PPD) usually happens after birth where the patient typically suffers from loneliness, hopelessness, deep sadness, fatigue, fear about baby disconnection and fears about harming her newborn (9). Seasonal Affective Disorder generally occurs in winter, probably due to a shortage of sunlight. Symptoms are generally mild to severe. This type usually lasts in spring and natural or artificial light is usually the suitable treatment (10).

Atypical Depression is commonly associated with physical symptoms, including a sense of heaviness in the legs or arms together with being overweight and problems with social communication (11). Psychotic Depression is characterized by psychological symptoms including delusions, and auditory and visual hallucinations (12). In Bipolar Disorder, patients have a cycle of depression and mania symptoms. It is classified into bipolar I (where patients have at least one manic episode) (13); bipolar II (where patients have hypomania as well as depression) (14) and cyclothymia, a cycle of depression followed by a cycle of mania (15). Premenstrual Dysphoric Disorder occurs in females during the last 2 weeks of the menstrual cycle (16). Situational Depression is related to certain stressful situations and the symptoms are unhappiness, anxiety and perhaps major depression (17) (Fig. 2).

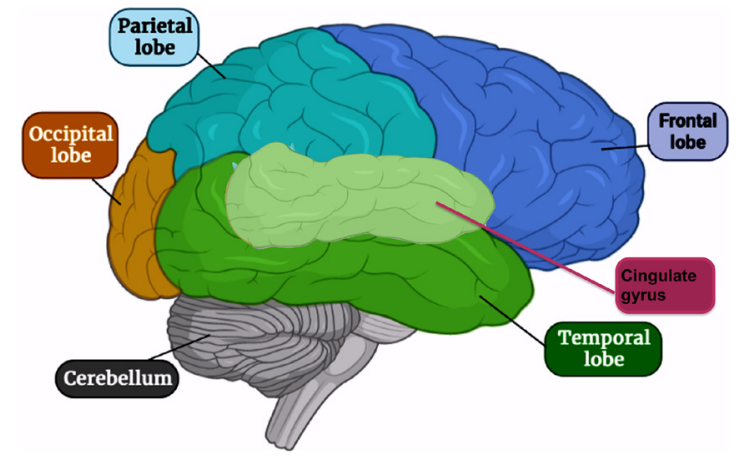

Figure 1. Areas affected in the brain during depression. The areas affected in the brain include the temporal and frontal lobes and the cingulate gyrus of the limbic system.

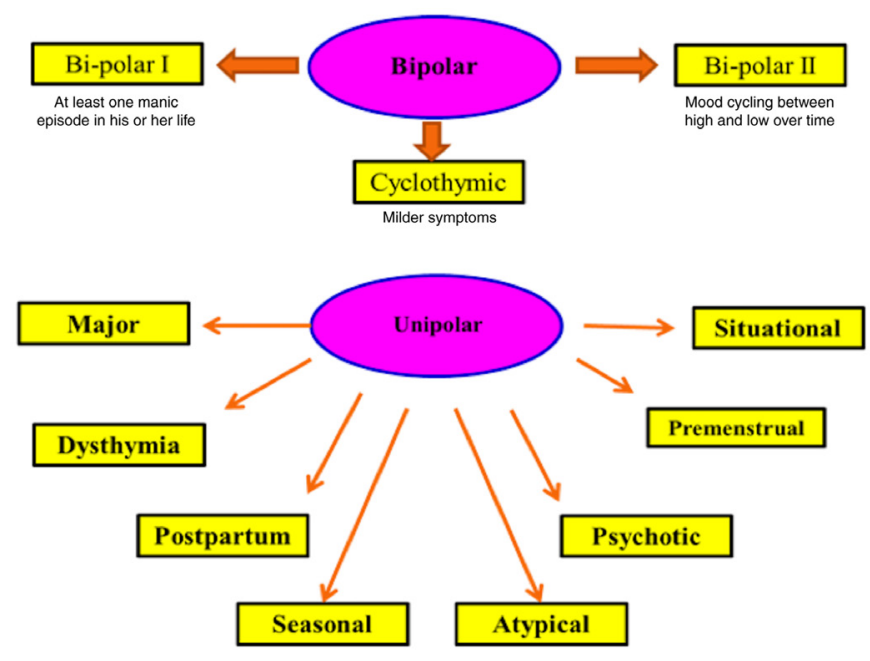

Figure 2. Common types of depression. Types of depression include unipolar (unipolar I, II and cyclothymia) and bipolar (major, dysthymia, postpartum, seasonal, atypical and psychotic).

Depression can be treated by non-drug or drug-containing therapy. None-drug treatment includes encouraging creativity, physical or alternative therapy including exposure to sunlight, St. John's Wort and acupuncture (18). On the other hand, well-known antidepressant drugs including selective serotonin reuptake inhibitors (SSRIs), tricyclic antidepressants (TCAs), norepinephrine reuptake inhibitors (NRIs), serotonin antagonist and reuptake inhibitors (SARIs) and serotonin-norepinephrine reuptake inhibitors (SNRIs) are used (19). However, efforts have been made to find new antidepressants with high efficacy and faster response, fewer side effects, able the preserve sexual functions in patients, improved efficacy, rapid onset and improved safety profile. Mental health problems resulting from the COVID-19 pandemic comprise insomnia, anxiety, stress, fear and depressive behavior (20). So far, there have been no data about the changes in cognitive functioning or emotions from the direct effects of the virus on the brain. A proportion of the world's population are in health quarantine and isolated at home and have lost their jobs, family members, relatives, colleagues, or friends. Consequently, depression associated with COVID-19 can be included under a situational or emotional type of depression. 
Table I. Common medical disorders and drug therapies associated with depression (27).

Type of disorder/therapy

Name of disorder/therapy

\section{Medical disorders \\ Deficiency situations \\ Infections \\ Collagen disorder \\ Endocrine diseases \\ Neurologic disorders \\ Metabolic disorders \\ Cardiovascular disease \\ Malignant disease \\ Psychiatric disorders \\ Hormonal therapy \\ Drug therapy}

Acne therapy

Other

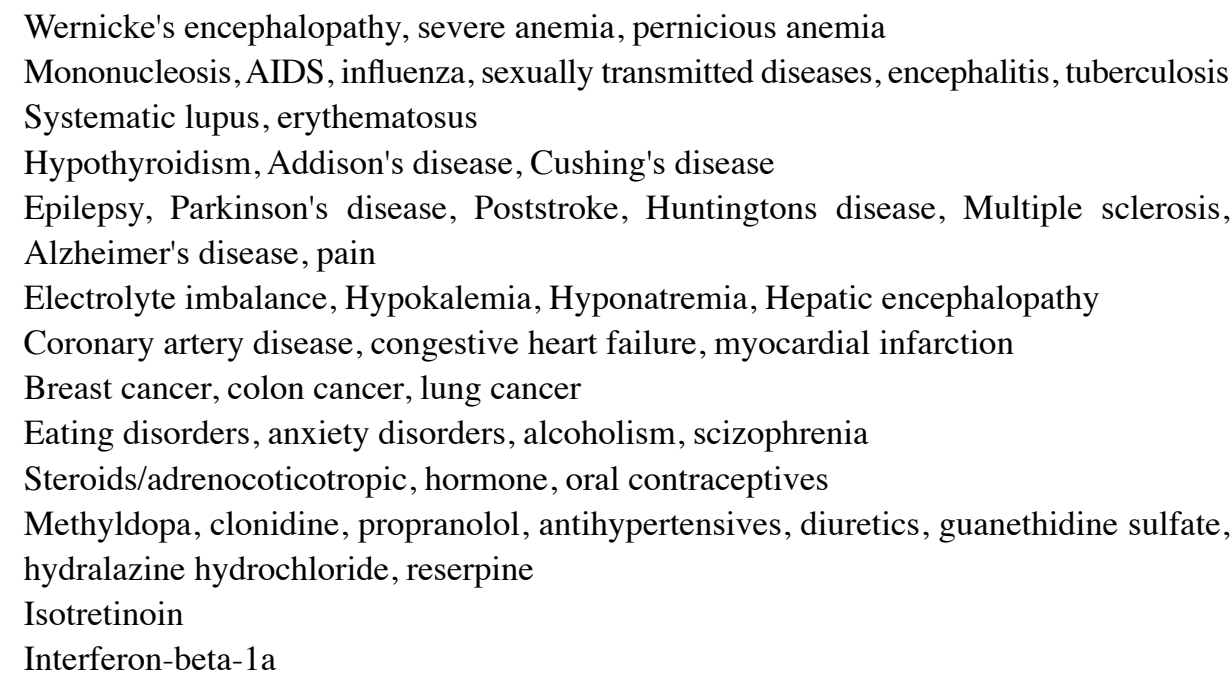

Wernicke's encephalopathy, severe anemia, pernicious anemia

Mononucleosis, AIDS, influenza, sexually transmitted diseases, encephalitis, tuberculosis Systematic lupus, erythematosus

Hypothyroidism, Addison's disease, Cushing's disease

Epilepsy, Parkinson's disease, Poststroke, Huntingtons disease, Multiple sclerosis, Alzheimer's disease, pain

Electrolyte imbalance, Hypokalemia, Hyponatremia, Hepatic encephalopathy

Coronary artery disease, congestive heart failure, myocardial infarction

Breast cancer, colon cancer, lung cancer

Eating disorders, anxiety disorders, alcoholism, scizophrenia

Steroids/adrenocoticotropic, hormone, oral contraceptives

Methyldopa, clonidine, propranolol, antihypertensives, diuretics, guanethidine sulfate, hydralazine hydrochloride, reserpine

Interferon-beta-1a

\section{Epidemiology}

According to the World Health Organization (WHO), 264 million individuals worldwide suffer from major depression. Almost 800,000 suicides are counted each year and it is the second leading cause of death among young individuals (21). Adolescents aged between 12 and 17 years exhibit the highest rate of major depressive episodes $(11.3 \%)$ followed by young adults between 12 and 20 years old at $9.6 \%$ (22). It has been observed that adults $>50$ years of age are less likely to have major depressive episodes (4.5\%) (23). The rate of moderate to severe depression increased from 23.2 to $41.1 \%$ from 2007 to 2018 (24). It is noted that the prevalence of depression among women is almost twice as high as that of men (25). Despite the availability of effective antidepressants with multiple mechanisms of action, it has been observed that between 76 and $85 \%$ of individuals who belong to developing countries do not receive any treatment for depression $(25,26)$.

\section{Biological markers and clinical presentation of depression}

There are no specific biological markers for depression. Various medical and psychiatric disorders, as well as certain drugs, have been noted in patients with depressive illness (Table I) (27).

In all, $25 \%$ of patients with a chronic medical history, including cancer, diabetes, or cardiovascular diseases, develop depressive disorder without a clear and accurate diagnosis for depression (28). According to the DSM-5, the symptoms of major depression are sadness, anxiety or irritability, feelings of guilt and suicidal thoughts (29). The clinical presentation could be classified into emotional and physical symptoms. Emotional symptoms include stress, sadness, anxiety, or feeling guilty, whereas physical symptoms may include sleep disturbance, appetite changes, headache, pain, or fatigue (Table II).
Table II. Physical and emotional symptoms in depression (163).

\begin{tabular}{ll}
\hline Emotional symptoms & \multicolumn{1}{c}{ Physical symptoms } \\
\hline Stress & Lack of energy \\
Sadness and tearfulness & Tiredness/fatigue \\
Loss of interest & Body aches and pains \\
Anxiety/irritability & Sleep disturbances \\
Hopelessness & Headaches \\
Concentration difficulties & Psychomotor activity changes \\
Feelings of guilt & GI disturbances \\
Suicidal thoughts & Changes in appetite \\
\hline
\end{tabular}

\section{Depression and common medical diseases}

Depression can cause several medical diseases, including Alzheimer's (by 2.0-fold) (30), cardiovascular diseases (1.52.0-fold) (31), stroke (1.8-fold) (31), epilepsy (4.0-6.0-fold) (32), diabetes (1.6-fold) (33) and cancer (1.3-1.8-fold) (34) (Fig. 3). Drugs used in controlling depressive illness have multiple unwanted effects, including increased weight, sedation, sexual dysfunction, indigestion, or decreased blood pressure. Incompliance or stopping medication may cause a relapse of the symptoms of depression and pose a risk of attempted suicide (35).

\section{Depression and the metabolic diseases}

Depression is usually accompanied by metabolic syndrome, obesity and type-2 diabetes (36,37). In diabetes, $20.9 \%$ of males and $27 \%$ of females exhibit major depression in western Kenya (38). By contrast, depression may increase the risk for diabetes (33). Gastrointestinal hormones, 


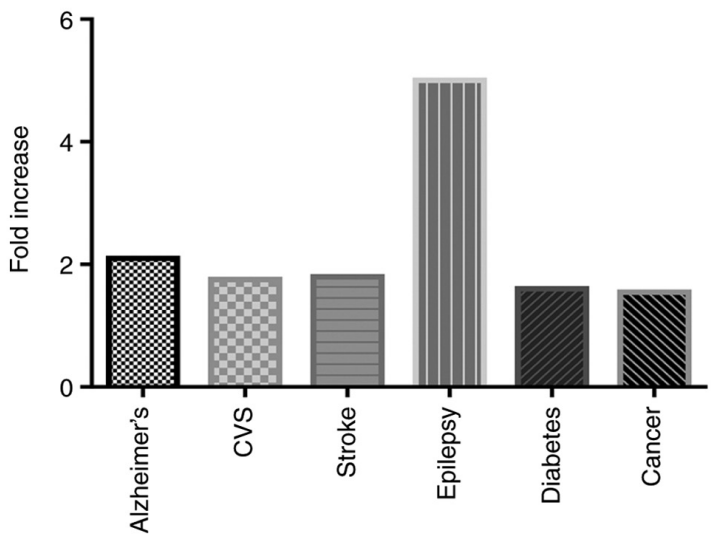

Figure 3. Fold increase in the risk of diseases resulting from depression. Depression can cause several medical diseases, including Alzheimer's (by 2.0 -fold), CVS (1.5-2.0-fold), stroke (1.8-fold), epilepsy (4.0-6.0-fold), diabetes (1.6-fold) and cancer (1.3-1.8-fold) compared with control non-depressed individuals. CVS, cardiovascular disease.

including ghrelin, leptin and the lipid endocannabinoid, may regulate mood in the case of depression (39). Improving the depression symptoms has been accompanied by inhibition of cholecystokinin receptors in mice and also inhibits the hyperactivity of the hypothalamic-pituitary-adrenal axis (40). Neuroendocrine, noradrenergic and serotonergic are controlled by the galanin neuropeptide systems in depression and anxiety-related behaviors (41). Furthermore, hippocampal neurogenesis is induced by an insulin-like growth factor (IGF) and the disturbance of neuronal IGF results in depression (42). Regulation of synaptic plasticity and improving depressive behavior results from releasing gastrinreleasing peptide in the hippocampus (43) (Fig. 4).

\section{Depression and endocrine disorders}

Cushing's syndrome and hypothyroidism are accompanied by a high rate of psychiatric morbidity (44). Secondary hypothyroidism is normally characterized by decreased blood level thyroid-stimulating hormone, which is concomitant with an increased risk of depressive episodes (45). It is found that $40 \%$ of patients with hypothyroidism suffer from clinical depression $(46,47)$. Hyperthyroidism patients have a high risk of depression by $28 \%$ compared with normal individuals, whereas it occurs in $50 \%$ of all cases of patients with hypothyroidism $(46,48)$. Blood and cerebrospinal levels of T4 are relatively increased during the depression (46) (Fig. 5). The raised concentration of corticotropin-releasing factor in cerebrospinal fluid in patients with depression is noted in a previous study (49).

\section{Depression and cardiovascular diseases}

Decreased plasma volume and elevation in blood viscosity lead to a higher risk of depression $(50,51)$. Patients with depression have a high risk for hypertension, congestive heart failure and myocardial infarction (52). Hypercoagulability, platelet activation and $\mathrm{D}$-dimer proteins can be detected in patients with depression $(50,53,54)$. In clinical trials, the risk of depression is significantly reduced in cardiovascular disease

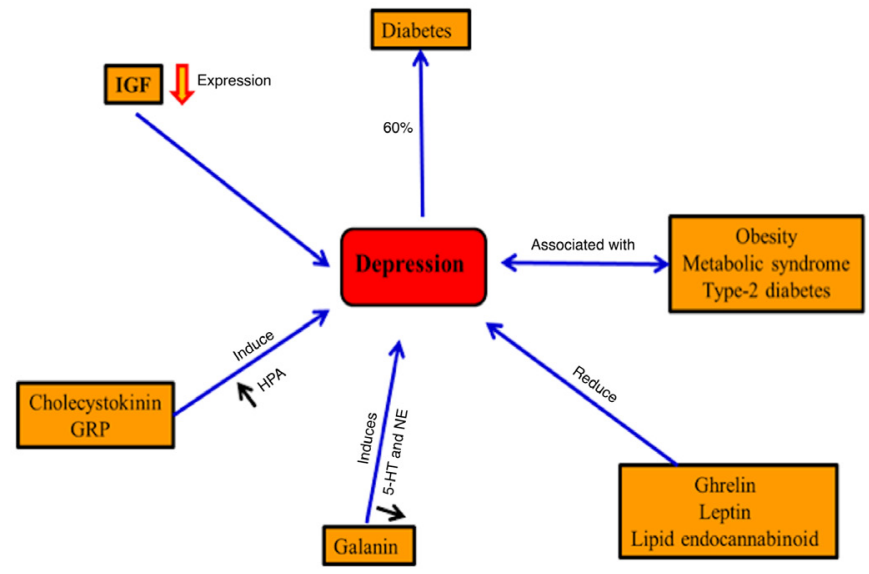

Figure 4. Depression and metabolic disorders. Depression is accompanied by metabolic syndrome, obesity, T2DM and T1DM (30,31,38, respectively). By contrast, depression may increase the risk of diabetes. Gastrointestinal hormones, such as ghrelin, leptin and the lipid endocannabinoid, may regulate mood in the case of depression. Improving depression symptoms has been accompanied by inhibition of cholecystokinin receptors and the hyperactivity of the HPA axis. Hippocampal neurogenesis is induced by IGF and the disturbance of neuronal IGF results in depression. Regulation of synaptic plasticity and improving depressive behavior results from releasing gastrin-releasing peptide in the hippocampus. HPA, hypothalamicpituitary-adrenal; IGF, insulin-like growth factor; GRP, gastrin-releasing peptide; 5-HT, 5-hydroxytryptamine; NE, norepinephrine.

patients treated with statins $(50,55)$. It has been demonstrated that vascular endothelial growth factor has neurogenic/neuroprotective effects $(50,56,57)$. Furthermore, its level is notably increased in patients diagnosed with depression $(58,59)$.

\section{Depression and inflammatory status}

Depression increases cytokines, IL-6, TNF- $\alpha$ and IL-1 (60). Furthermore, stress regulates prostaglandin-E2, lipid peroxidation IL-1 $\beta$, cyclooxygenase-2 and Toll-like receptor-4 (Fig. 6). A previous study demonstrates that celecoxib can be used as a new strategy for major depression, especially bipolar disorder $(61,62)$. In addition, Nery et al (63) describe the antidepressant action of celecoxib, which is characterized by its rapid-onset antidepressant activities. Sesamol, a potent antioxidant and cytokine inhibitor, has been shown to improve chronic stress-induced depression in an experimental mouse model (64).

\section{Depression and daylight}

Deficiency of light has been shown to suppress neurogenesis and increase symptoms of depression (65). Nocturnal melatonin, vitamin D and platelet 5-HT values are induced by environmental light and improve depression symptoms $(66,67)$. Melatonin has anti-oxidative effects, increases sleep propensity and has been known to decrease alertness and attenuate weight gain (68) (Fig. 7).

\section{Depression in the deficiency state}

Intake of omega-3 fatty acids, fish, vitamin B6, vegetables, fruits, folate, olive oil, vitamin B12, nuts and legumes improves 


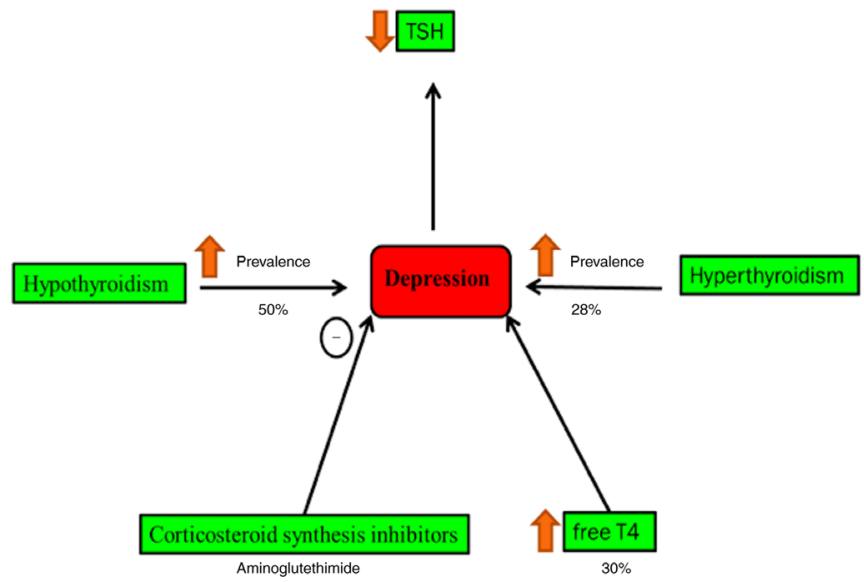

Figure 5. Depression and endocrine disorders. Cushing's syndrome and hypothyroidism are accompanied by a high rate of psychiatric morbidity The raised concentration of thyrotrophin releasing hormone in cerebrospinal fluid in patients with depression is noted in a previous study. Secondary hypothyroidism is characterized by decreased blood level thyroid-stimulating hormone, which is concomitant with an increased risk of depressive episodes. It is found that $40 \%$ of patients with hypothyroidism suffer from clinical depression. Hyperthyroidism patients have a high risk of depression by $28 \%$ compared with normal individuals, whereas it occurs in $50 \%$ of all cases of patients with hypothyroidism. Blood and cerebrospinal levels of T4 are relatively increased during the depression. T4, thyroxin; TSH, thyroid stimulating hormone.

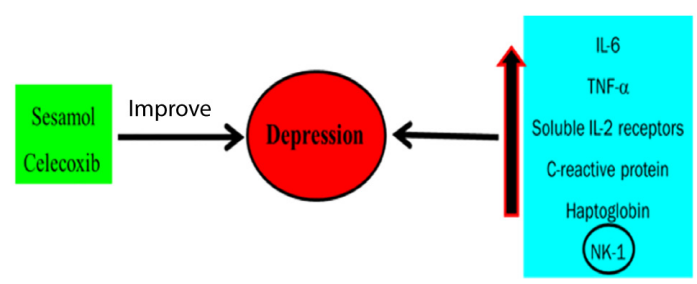

Figure 6. Depression and inflammatory disorders. Depression increases cytokines, including IL-6, TNF- $\alpha$ and IL-1. Furthermore, stress regulates prostaglandin-E2, lipid peroxidation IL-1 $\beta$, cyclooxygenase-2 and Toll-like receptor-4. NK-1, neurokinin-1 receptor.

depressive symptoms although the exact mechanism remains to be elucidated $(69,70)$.

A previous study demonstrates that unipolar depression can be effectively controlled by folic acid (71). A study conducted on >70 patients showed that major depressive disorder in non-responders to SSRIs could be improved by s-adenosyl methionine if taken concurrently with serotonin reuptake inhibitor (72) (Fig. 8).

\section{Depression and glutamate}

The ionotropic glutamate receptors N-methyl-D-aspartate (NMDA), $\alpha$-amino-3-hydroxy-5-methyl-4-isoxazolepropionic acid and metabotropic glutamate receptors (mGluR1 to mGluR8) activation regulate synaptic plasticity and transmission. Glutamate is cleaned by high-affinity excitatory amino acid transporters (EAAT) 1 and 2 from extracellular space found in glial cells (73).

Following the conversion of the glial cells glutamate to glutamine, by glutamine synthetase, glutamine is hydrolyzed into glutamate via glutaminase (74). In experimental animal

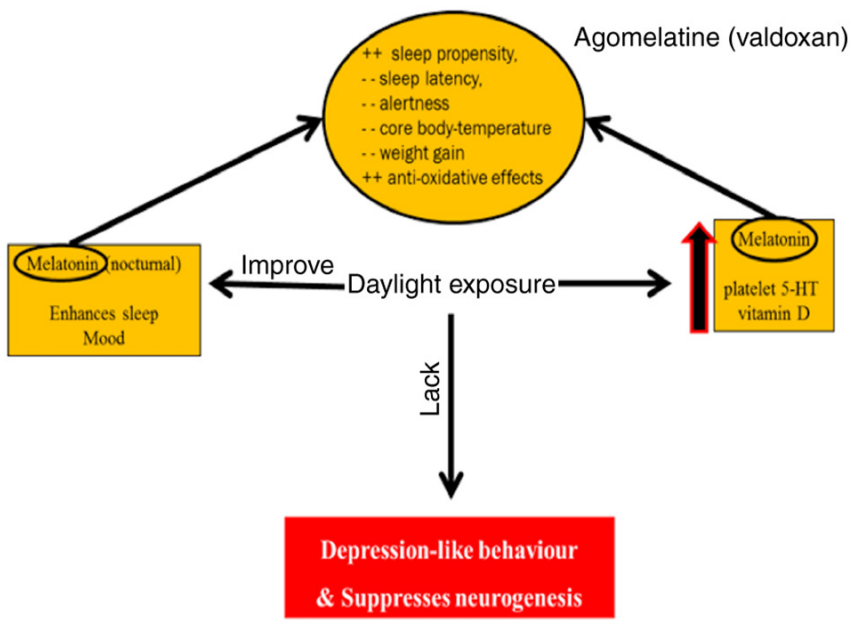

Figure 7. Depression and daylight. Deficiency of light has been shown to suppress neurogenesis and increase symptoms of depression. Nocturnal melatonin, vitamin D and platelet 5-HT values are induced by environmental light and improve depression symptoms. Melatonin has anti-oxidative effects, increases sleep propensity and has been known to decrease alertness and attenuate weight gain. 5-HT, 5-hydroxytryptamine.

models of depression, drugs that increase glutamate clearance can improve stress and possess antidepressant effects $(75,76)$.

Ketamine N-methyl-D-aspartate receptor antagonist in subanesthetic dose $(0.5 \mathrm{mg} / \mathrm{kg})$ has a short onset antidepressant effect (77). Another rapid-acting antidepressant is dextromethorphan (NMDA receptor antagonist) (78). The antimuscarinic drug scopolamine has short onset with a potent antidepressant effect for bipolar and major depression $(79,80)$. As with NMDA receptor antagonists, zinc and magnesium have an antidepressant effect in experimental animal models (81). It has been stated that magnesium has an antidepressant effect in type II diabetic patients, compared with imipramine (82).

\section{Depression in neurodegenerative cases}

Long-time stress may negatively affect the process of neurogenesis and cause neuronal loss in the hippocampus $(83,84)$. In depressive behaviors, synaptic plasticity has been revealed to be controlled by brain-derived neurotrophic factor (BDNF) $(85,86)$. The blood level of BDNF is decreased in patients with depression and its level is increased by antidepressant drugs $(87,88)$.

In patients with depression, a decreased level of vascular growth factor (VGF) has been shown (89) and an antidepressant effect is produced by treatment with recombinant VGF in an experimental animal model (90). Neurotrophin-3 and nerve growth factor may contribute to the antidepressant responses by improving plasticity and neurogenesis in the hippocampus $(91,92)$. Other factors such as glial cell linederived neurotrophic factor and fibroblast growth factor- 2 are modulated in depression $(58,93)$ (Fig. 9).

\section{Depression and oxidative stress}

In patients with depression, numerous enzyme-mediated reactive oxygen species (ROS) production is increased (94). Superoxide and hydrogen peroxide are products of oxidation of xanthine mediated by xanthine oxidase enzyme that has been 


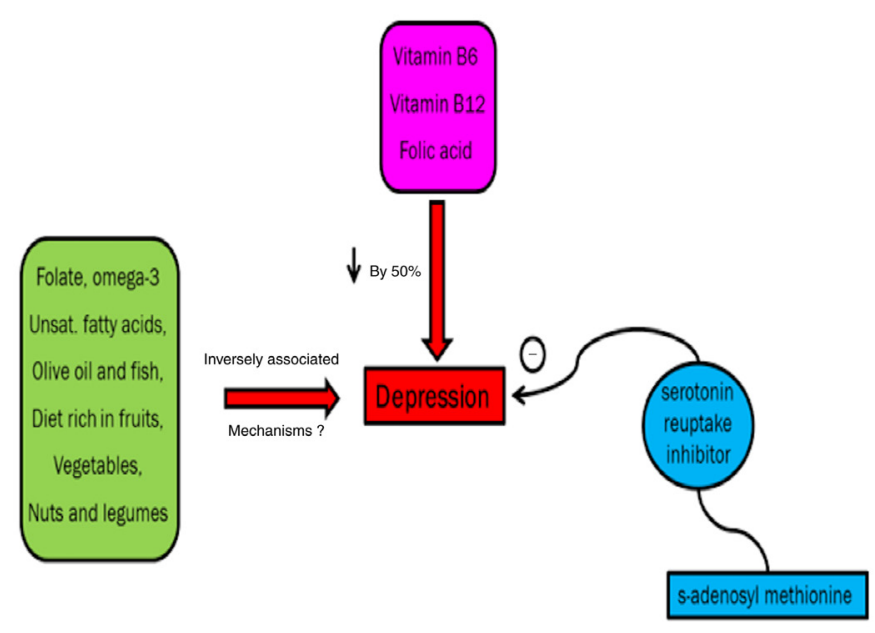

Figure 8. Depression and deficiency. Intake of omega-3 fatty acids, fish, vitamin B6, vegetables, fruits, folate, olive oil, vitamin B12, nuts and legumes improves depressive symptoms, although the exact mechanism remains to be elucidated. A previous study demonstrates that unipolar depression can be effectively controlled by folic acid. A study conducted on $>70$ patients showed that major depressive disorder in non-responders to selective serotonin reuptake inhibitors could be improved by s-adenosyl methionine if taken concurrently with serotonin reuptake inhibitor.

found to increase in the thalamus in postmortems of patients with depression (95). Metabolism and oxidative deamination of serotonin are exaggerated by monoamine oxidase, which can cause ROS production leading to mitochondrial dysfunction and neuronal apoptosis (96). In addition, COX-2 is involved in the inflammatory cascades and its inhibitors can lead to neuronal inflammation that may worsen depression (97). Decreased superoxide dismutase activity is shown in patients diagnosed with depression (98). Peroxides, such as hydrogen peroxide catalyzed by glutathione peroxidase, have lower activity in patients with depression compared to healthy individuals (99). Microglia are the main inflammatory neuronal cells that are activated by the increased levels of superoxide and other ROS (100). This activated cell releases a number of inflammatory cytokines, mostly TNF- $\alpha$ and IL-6 (101).

It has been demonstrated that an increased level of nitric oxide (NO) mediates the 3',5'-cyclic guanosine monophosphate (cGMP) signaling pathway leading to depressive symptoms; however, the reduction of NO and/or cGMP results in improvement in depression-like symptoms in experimental animal models (102). The elevated level of NO may react with superoxide anions and produce highly reactive inflammogenic and neurotoxic peroxynitrite and consequently a local surge in inflammatory cytokines (103). The previous NO effects are involved in the pathogenesis of major depression (104), Parkinson's disease and Alzheimer's (103).

\section{Gene expression in depression}

There are differences in the cortical gene expression in patients with schizophrenia, bipolar disorder and autism including differentiation of the glial cell and metabolism of fatty acid $(105,106)$. Notably, the pathophysiology of major depression (MD) involves inflammatory pathways and the hypothalamic-pituitary axis (107). Another study found low expression of two genes, ATP binding cassette subfamily G

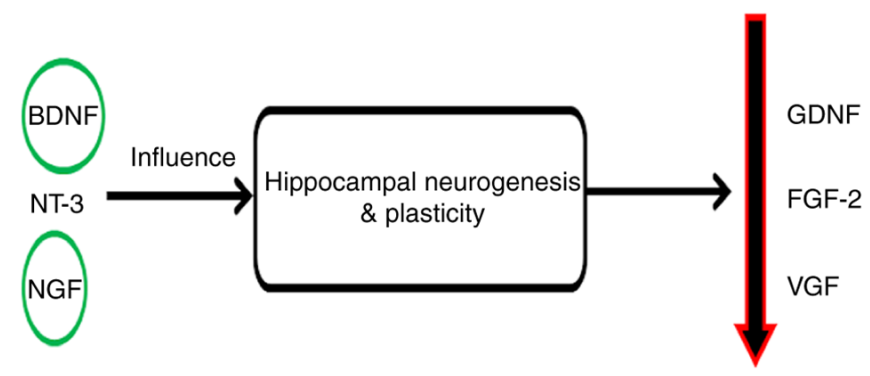

Figure 9. Depression and neurodegenerative cases. Long-time stress may negatively affect the process of neurogenesis and cause neuronal loss in the hippocampus. In depressive behaviors, synaptic plasticity has been revealed to be controlled by BDNF. The blood level of BDNF is decreased in patients with depression and its level is increased by antidepressant drugs. In patients with depression, a decreased level of VGF has been shown and an antidepressant effect is produced by treatment with recombinant VGF in an experimental animal model. NT-3 and NGF may contribute to the antidepressant responses by improving plasticity and neurogenesis in the hippocampus. Other factors, such as GDNF and FGF-2, are modulated in depression. BDNF, brain-derived neurotrophic factor; VGF, vascular growth factor; NT-3, neurotrophin-3; NGF, nerve growth factor; GDNF, glial cell line-derived neurotrophic factor; FGF-2, fibroblast growth factor-2.

member 2 and prominin 1 in patients with MD (108). Similarly, a low level of mRNA encoding the gene Fli-1 proto-oncogene, ETS transcription factor has been found and it serves a role in the growth of the neuronal crest in patients with depression (109). Reduction in the expression of SLC1A2 and SLC1A3 genes has been found in the dorsolateral prefrontal cortex and anterior cingulate of patients with MD and bipolar disorder (110). A lower expression of NMDA receptor subunits was found in patients with MD including PSD-95, NR1, NR2A and NR2B in the anterior prefrontal cortex (111). GABA signaling-related genes such as ALDH9A1 and glutamate ammonia ligase, are changed in patients with depression (112). ALDH9A1, which catalyzes the conversion of $\gamma$-aminobutyraldehyde into GABA, was increased in depressed subjects, whereas glutamate ammonia ligase, which increases glutamate brain clearance by its conversion to glutamine, was decreased in depressed brain. Furthermore, decreased activation and functions in the gene expression of the extracellular signal-regulated kinase (ERK) cascade is recorded in MD (113). Several deviations in the gene expression in MD were found to be gender-specific, occurring mostly in females. For instance, hub gene Dusp6 (female-specific gene) is downregulated in female, but not male mice prefrontal cortex simulated stress by increasing pyramidal neuron excitability and ERK signaling. This gender-specific feature in MD patients could be due to changes in the specificity of ventromedial cortex content of phosphatase 6 in female patients and empty spiracles homeobox 1 in males (113).

\section{Treatment of depression}

\section{None drug treatment}

Encouraging creativity. Reading books or journals, gardening, painting and playing music can offer a passage to drive out the painful thoughts and bad moods. It is known that creative individuals are at high risk for depression than non-creative ones (114). 
Physical therapy. In this, patients with depression are directed to perform physical exercise. The only challenge facing this strategy is that patients with depression often suffer from a lack of energy. However, starting a new physical activity can be influential in managing such symptoms. Performing physical exercise is known to produce euphoria by releasing endorphins (115).

Psychiatric therapy. Cognitive Behavioral Therapy is a common psychotherapy strategy used in the treatment of depression. This strategy directs patients to correct negative non-constructive thinking (116).

Alternative therapy. A $40 \mathrm{~min}$ exposure to sunlight by patients suffering from seasonal depression results in a good response (117). This type of therapy may be helpful in patients suffering from seasonal depression. St. John's Wort and acupuncture are used and can improve depressive behavioral symptoms (118).

Antidepressant drugs. Most antidepressants employ important activities on the metabolism of monoamine neurotransmitters and their receptors, mainly norepinephrine and serotonin (119). The well-known antidepressant classes include SSRIs, TCAs, NRIs, SARIs, SNRIs and noradrenaline and dopamine reuptake inhibitors (Tables III-IX) (120).

\section{Other antidepressants}

LY03005 (Ansofaxine hydrochloride). Ansofaxine is developed by Luye Pharma Group for the treatment of major depression. The American food and drug administration (FDA) approved the serotonin-norepinephrine-dopamine triple reuptake inhibitor LY03005 in December 2020 under the name of Ansofaxine (121). It was developed under Luye pharma's new chemical and therapeutic entities research and development platform (122). Triple reuptake inhibitors encourage a class of antidepressants and are considered to have high efficacy and faster antidepressant response. They have relative advantages in preserving patients' sexual functions, improved efficacy, rapid onset and improved safety profile (122).

Duloxetine. Duloxetine hydrochloride (Cymbalta) is an oral selective serotonin and norepinephrine reuptake inhibitor. It has been accepted in the treatment of different mental disorders, including depressive behavioral illness (123). One important benefit that leads to the use of duloxetine in the treatment of depression is its effect in the prevention of suicidal thoughts and attempts (124). Wu et al (125) demonstrate that duloxetine may be effective in the treatment of epileptic patients with depression. A recent study demonstrated that a spray-dried complexationbased transdermal patch of duloxetine functions as a possible new drug delivery system in the treatment of depression (126).

Vilazodone (Viibryd). Vilazodone was approved by the FDA in January 2011 and it is the first and only selective serotonin reuptake inhibitor and 5-HT1A receptor partial agonist (127). A large dose of vilazodone is accompanied by acute serotonin syndrome. Some serious uncommon adverse effects include suicidal thoughts, sexual dysfunction, manic behavior, serotonin syndrome and hyponatremia (128).
GLYX-13 (Rapastinel). GLYX-13 finalized phase II in 2015 and on January 29, 2016 Allergan company reported that Rapastinel had received approval from the FDA for treatment of major depression (129). GLYX-13 functions by controlling the neuronal N-methyl-D-aspartate (NMDA) receptor. Although it is similar to ketamine receptor antagonists of NMDA, GLYX-13 does not cause severe adverse effects such as schizophrenic symptoms and hallucinations effects (130).

Vortioxetine (Brintellix). Brintellix, used for the treatment of major depression, is recently available in the United States markets (131). The antidepressant mechanism of Brintellix remains to be elucidated. Vortioxetine is a 5-HT1D, 5-HT3 and 5-HT7 receptors antagonist, 5-HT1B partial receptors agonist and 5-HT1A receptor agonist (132). Plasma concentration of BDNF shows a significant increase and the concentration of platelet 5-HT displays significant reduction following Brintellix administration in patients with major depression (129).

Agomelatine (Valdoxan). Valdoxan targets the melatonin system in the brain and is considered a melatonergic drug. It was approved for the treatment of major depression in Europe in 2009. It has been recently reported that Agomelatine is effective in PPD treatment and is safe during breastfeeding (133). Agomelatine works by targeting the neuronal effects of melatonin, which has an essential role as an antidepressant. Similar to serotonin, agomelatine appears to be important in controlling sleep and circadian rhythms $(134,135)$.

Ketamine. It is an anesthetic drug that has an antidepressant effect but is not yet accepted as an antidepressant by the FDA. Ketamine acts on a number of central nervous system receptors responsible for learning and memory. These receptors work on the excitatory neurotransmitter, glutamate (136), which activates mTORC1 kinase via inactivation of eukaryotic initiation factor 4E-binding proteins (137). Intranasal spray of ketamine was FDA approved as an antidepressant. Finally, the safety and efficacy of ketamine in depression control requires further investigation (138).

Levomilnacipran. Levomilnacipran is a rapid onset drug used for treatment of depression that belongs to a class of SNRIs. There is no evidence to indicate any relative advantages of levomilnacipran compared with available SNRIs (139). A recent study demonstrated that levomilnacipran in older patients with depression has lower tolerability than in older adults with depression. Levomilnacipran requires to be more deeply studied to analyze its efficacy and tolerability in patients with depression (140).

Quetiapine (Seroquel XR). Although it inhibits nerve communication between the brain areas, like other atypical anti-psychotics, the mechanism of quetiapine remains to be elucidated. A promising result of SNRI (Venlafaxine) and Quetiapine co-treatment in patients with depression has been reported (141). The benefits of Quetiapine may be due to inhibition of the serotonin type 2 and dopamine type 2 
Table III. Mono amino oxidase inhibitors (120).

\begin{tabular}{|c|c|c|c|c|c|}
\hline Drug & Selectivity & $\begin{array}{c}\text { FDA } \\
\text { approval }\end{array}$ & $\begin{array}{l}\text { Common } \\
\text { adverse } \\
\text { effects } \\
>10 \% \\
\text { incidence }\end{array}$ & $\begin{array}{l}\text { Administration } \\
\text { in pregnancy }\end{array}$ & Interactions \\
\hline Isocarboxazide & $\begin{array}{l}\text { Non- } \\
\text { selective } \\
\text { MAOIs }\end{array}$ & 1959 & $\begin{array}{l}\text { Weight gain, chills } \\
\text { orthostatic hypotension, } \\
\text { forgetful, headache, } \\
\text { sexual dysfunction, } \\
\text { lethargy, constipation, } \\
\text { dizziness, serotonin } \\
\text { syndrome }\end{array}$ & No data & $\begin{array}{l}\text { Salmeterol, trazodone, } \\
\text { alcohol, citalopram, } \\
\text { zolpidem, duloxetine, } \\
\text { amitriptyline, venlafaxine, } \\
\text { escitalopram, phenelzine } \\
\text { and lisdexamfetamine. }\end{array}$ \\
\hline Phenelzine & & 1961 & $\begin{array}{l}\text { Dizziness, confusion, } \\
\text { chills, tremors, } \\
\text { drowsiness, weakness, } \\
\text { insomnia and } \\
\text { dry mouth }\end{array}$ & No data & $\begin{array}{l}\text { Citalopram, duloxetine, } \\
\text { dextromethorphan, } \\
\text { meperidine, fentanyl, } \\
\text { tryptophan, } \\
\text { lisdexamfetamine and } \\
\text { vilazodone. }\end{array}$ \\
\hline Selegiline & & 1998 & $\begin{array}{l}\text { Orthostasis, dizziness, } \\
\text { nausea and abdominal } \\
\text { pain }\end{array}$ & No & $\begin{array}{l}\text { Duloxetine, escitalopram, } \\
\text { meperidine, rasagiline, } \\
\text { bupropion and } \\
\text { amphetamine }\end{array}$ \\
\hline Tranylcypromine & $\begin{array}{l}\text { Selective } \\
\text { MAO-A } \\
\text { inhibitors }\end{array}$ & 1961 & $\begin{array}{l}\text { Anxiety, dizziness, } \\
\text { weakness and } \\
\text { constipation. }\end{array}$ & No data & $\begin{array}{l}\text { Duloxetine, citalopram, } \\
\text { selegiline, phenelzine, } \\
\text { escitalopram, paroxetine, } \\
\text { pseudoephedrine and } \\
\text { lisdexamfetamine. }\end{array}$ \\
\hline Brofaromine & & 1995 & $\begin{array}{l}\text { Tremor, sleep } \\
\text { disorders, dry mouth } \\
\text { and hypotension }\end{array}$ & No data & $\begin{array}{l}\text { Warfarin, amantadine, } \\
\text { amitriptyline, apomorphine, } \\
\text { benzodiazepine, bupropion, } \\
\text { dobutamine, duloxetine } \\
\text { and ethanol. }\end{array}$ \\
\hline
\end{tabular}

MAO, mono amino oxidase.

receptors (142). Hazards of mortality, suicidal thoughts and stroke in the elderly are common among patients treated with Quetiapine (143).

\section{COVID-19 and depression}

The outbreak of COVID-19 seriously influences mental health. The pandemic represents a stressful situation worldwide and at the time of writing this review, the confirmed cases are $>177,108,695$ including 3,840,223 mortalities (WHO; https://covid19.who.int). Mental health problems resulting from this pandemic include insomnia, anxiety, depressive behavior, stress and fear (144). In the aftermath of the COVID-19 pandemic, depression and anxiety are common psychological complaints (145). Lai et al (146) observed the mental health status during the COVID-19 pandemic in 1,257 doctors and other healthcare staff in China. It was found that $71.5 \%$ of the study sample claimed distress, $50.4 \%$ depression, $44.6 \%$ anxiety and $34.0 \%$ insomnia. In addition, a possible correlation between the symptoms in COVID-19 patients and potential neurological consequences has been found (147). At present, nothing is known about the changes in cognitive functioning or emotions from the direct effects of the virus on the brain. A number of individuals are in health quarantine and isolated at home and have lost their jobs, family members, relatives, colleagues, or friends. Accordingly, depression due to COVID-19 may be included under the situational or emotional type of depression.

There are a number of drugs under investigation in different research institutes, universities, or under clinical trials in hospitals. The investigational drugs include Baricitinib, interferon- $\beta$ 1b, Bemcentinib, Bevacizumab, chloroquine phosphate, Colchicine, Dexamethasone, EIDD-2801, Favipiravir, Hydroxychloroquine, Azithromycin, anticoagulants, Lopinavir, Ritonavir and Remdesivir. The current use of some of these drugs in certain areas is marked with hopes and promises without attention being payed to their behavioral side effects and lethality. For example, Baricitinib (Olumiant R which is a Janus kinase inhibitor now in phase III clinical 
Table IV. Selective serotonin reuptake inhibitors (164).

\begin{tabular}{|c|c|c|c|c|}
\hline Drug & $\begin{array}{c}\text { FDA } \\
\text { approval }\end{array}$ & $\begin{array}{c}\text { Common } \\
\text { adverse effects } \\
>10 \% \text { incidence }\end{array}$ & $\begin{array}{l}\text { Administration } \\
\text { in pregnancy }\end{array}$ & Contraindications/interactions \\
\hline Cetalopram & 1998 & $\begin{array}{l}\text { Sexual dysfunction, } \\
\text { Sedation, drowsiness, } \\
\text { blurred vision, insomnia, } \\
\text { hypernatremia, nausea, eye } \\
\text { pain or swelling, vivid } \\
\text { dreaming, pounding } \\
\text { heartbeats, decreased } \\
\text { sex drive, anorgasmia, } \\
\text { dry mouth, trembling, } \\
\text { diarrhea and slurred } \\
\text { speech. }\end{array}$ & No & $\begin{array}{l}\text { Tryptophan, St John's Wort, } \\
\text { 5-HTP (serotonin syndrome), } \\
\text { cimetidine, lithium and } \\
\text { Omeprazole }\end{array}$ \\
\hline Escitalopram & 2002 & $\begin{array}{l}\text { Headache, nausea, } \\
\text { decreased libido, delayed } \\
\text { ejaculation, weight gain, } \\
\text { dose-dependent QT } \\
\text { interval prolongation on } \\
\text { the ECG. }\end{array}$ & $\begin{array}{l}\text { Has been linked } \\
\text { a very small } \\
\text { increased to risk } \\
\text { of problems for } \\
\text { your unborn baby. }\end{array}$ & $\begin{array}{l}\text { Substrates that increase } \\
\text { CYP2D6 such as codeine, } \\
\text { aripiprazole, or risperidone. } \\
\text { Acetaminophen, citalopram, } \\
\text { clonazepam, levothyroxine } \\
\text { or quetiapine }\end{array}$ \\
\hline Paroxetine & 1992 & $\begin{array}{l}\text { Loss of appetite, nausea, } \\
\text { asthenia diarrhea, blurred } \\
\text { vision, constipation, dry } \\
\text { mouth, somnolence, } \\
\text { insomnia, headache, } \\
\text { hypomania, nervousness, } \\
\text { paraesthesia, dizziness } \\
\text { and sexual dysfunction. }\end{array}$ & No & $\begin{array}{l}\text { MAOI, pimozide, } \\
\text { thioridazine, tryptophan, or } \\
\text { warfarin } \\
\text { Substrates of CYP2B6, } \\
\text { CYP3A4, CYP1A2, CYP2C9 } \\
\text { and CYP2C19. }\end{array}$ \\
\hline Fluoxetine & 1987 & $\begin{array}{l}\text { Headache, nausea, } \\
\text { agitation, insomnia, } \\
\text { appetite loss, Anxiety, } \\
\text { asthenia, diarrhea } \\
\text { and somnolence }\end{array}$ & $\begin{array}{l}\text { Major birth } \\
\text { defects during } \\
\text { the first } \\
\text { trimester. }\end{array}$ & $\begin{array}{l}\text { Inhibits a number of } \\
\text { isozymes of the cytochrome } \\
\text { P450 } \\
\text { Avoided with serotonergic } \\
\text { drugs such as } \\
\text { methamphetamine, MAOI, } \\
\text { buspirone, TCA, MDMA, } \\
\text { triptans and serotonin- } \\
\text { norepinephrine reuptake } \\
\text { inhibitors. }\end{array}$ \\
\hline Fluvoxamine & 1983 & $\begin{array}{l}\text { Nausea, headache, } \\
\text { anorexia, insomnia, } \\
\text { agitation, dizziness, } \\
\text { nervousness, anxiety, } \\
\text { somnolence, tremor and } \\
\text { palpitations. }\end{array}$ & No & $\begin{array}{l}\text { Fluvoxamine the following } \\
\text { cytochrome P450; } \\
\text { metabolizes agomelatine, } \\
\text { amitriptyline, caffeine, } \\
\text { alprazolam and aripiprazole. }\end{array}$ \\
\hline Sertraline & - & $\begin{array}{l}\text { Psychiatric side effects, } \\
\text { anxiety, agitation, } \\
\text { insomnia, sexual arousal } \\
\text { disorder and diarrhea }\end{array}$ & No & $\begin{array}{l}\text { Moderate of CYP2D6 } \\
\text { inhibitor and CYP2B6 } \\
\text { in vitro? }\end{array}$ \\
\hline
\end{tabular}

trials for COVID-19 treatment and has been used in the treatment of rheumatoid arthritis. Olumiant may occasionally lead to depression as a side effect (148).
Another drug that has been used recently in the treatment of COVID-19 is interferon- $\beta$ 1b. Clinical studies on the efficacy of interferon I $\alpha$ and interferon $\beta$ in SARS-CoV 
Table V. Tricyclic antidepressants (165).

\begin{tabular}{|c|c|c|c|c|}
\hline Drug & $\begin{array}{c}\text { FDA } \\
\text { approval }\end{array}$ & $\begin{array}{l}\text { Common } \\
\text { adverse effects } \\
>10 \% \text { incidence }\end{array}$ & $\begin{array}{l}\text { Administration } \\
\text { in pregnancy }\end{array}$ & Contraindications/interactions \\
\hline Amitriptyline & 1961 & $\begin{array}{l}\text { Anticholinergic side effects, } \\
\text { dizziness, headache, somnolence, } \\
\text { orthostatic hypotension, loss of } \\
\text { libido, agitation and insomnia }\end{array}$ & No & $\begin{array}{l}\text { Hypersensitivity, history of } \\
\text { myocardial infarction and } \\
\text { history of arrhythmias. } \\
\text { Monoamine oxidase inhibitors, } \\
\text { anticholinergic, antipsychotics, } \\
\text { cimetidine and antithyroid } \\
\text { medications. }\end{array}$ \\
\hline Butriptyline & Not & Similar to amitriptyline & No & Similar to amitriptyline \\
\hline Clomipramine & 1960 & $\begin{array}{l}\text { Dizziness, blurred vision, tremor, } \\
\text { sexual dysfunction, nausea, dry } \\
\text { mouth, fatigue, constipation, } \\
\text { weight gain and increased } \\
\text { appetite. }\end{array}$ & No & $\begin{array}{l}\text { MAOI, quinidine (metabolized } \\
\text { by CYP2D6) hypersensitivity, } \\
\text { myocardial infarction, } \\
\text { severe liver disease and narrow } \\
\text { angle glaucoma }\end{array}$ \\
\hline Desipramine & 1964 & $\begin{array}{l}\text { Cardiac dysrhythmias and } \\
\text { increased risk of breast cancer in } \\
\text { women }\end{array}$ & $\begin{array}{l}\text { Has not been } \\
\text { well studied }\end{array}$ & $\begin{array}{l}\text { Overactive thyroid gland, } \\
\text { schizophrenia, manic-depression, } \\
\text { alcoholism, suicidal thoughts, } \\
\text { closed angle glaucoma. } \\
\text { Aripiprazole, aripiprazole, } \\
\text { amphetamine duloxetine, } \\
\text { duloxetine, and lamotrigine. }\end{array}$ \\
\hline Dosulepin & Not & $\begin{array}{l}\text { Paraesthesias, drowsiness, } \\
\text { dizziness, sweating, } \\
\text { extrapyramidal symptoms } \\
\text { and tremor, hypotension, } \\
\text { confusion, disorientation, } \\
\text { ECG alterations, dry mouth } \\
\text { and urinary retention. }\end{array}$ & No & $\begin{array}{l}\text { Epilepsy, myocardial infarction } \\
\text { and hepatic failure. } \\
\text { Potentiate the effects of } \\
\text { alcohol, barbiturates, CNS } \\
\text { depressants and tranquillizers. }\end{array}$ \\
\hline Doxepin & Approved? & $\begin{array}{l}\text { CNS: fatigue, dizziness, } \\
\text { drowsiness, confusion and } \\
\text { nightmares. } \\
\text { Anticholinergic, allergy and } \\
\text { may increase or decrease } \\
\text { liver function in some patients. }\end{array}$ & No & $\begin{array}{l}\text { MAOI and potentiates } \\
\text { sympathomimetics } \\
\text { Hypersensitivities, glaucoma, } \\
\text { poor metabolizers and } \\
\text { respiratory impairment }\end{array}$ \\
\hline Imipramine & $1950 \mathrm{~s}$ & $\begin{array}{l}\text { CNS: Dizziness, drowsiness, } \\
\text { confusion, seizures, headache } \\
\text { and anxiety. } \\
\text { CVS: Orthostatic hypotension, } \\
\text { hypertension, tachycardia. } \\
\text { GIT: anorexia, epigastric distress, } \\
\text { diarrhea Hematological: bone } \\
\text { marrow depression. }\end{array}$ & - & - \\
\hline Iprindole & - & $\begin{array}{l}\text { Anticholinergic side effects } \\
\text { and sedation }\end{array}$ & $\begin{array}{l}\text { Inactivates } \\
\text { cytochrome }\end{array}$ & $\begin{array}{l}\text { Inactivates cytochrome } \mathrm{P} 450 \\
\text { Should not be taken by alcoholics } \\
\text { and those with liver disease. }\end{array}$ \\
\hline
\end{tabular}

had differing results. Interferon- $\beta$ 1b may increase the speed of COVID-19 viral clearance (149). The most serious side effects of interferon- $\beta-1 b$ in clinical trials are attempted suicide, depressive behavior and necrosis at the site of injection (150). Dexamethasone is a common and widely used synthetic steroid for a number of diseases, which can reduce mortality of seriously ill COVID-19 patients although with no improving effect in less serious cases (151). 
Table VI. Norepinephrine reuptake inhibitors (NRIs), (166).

\begin{tabular}{|c|c|c|c|c|}
\hline Drug & $\begin{array}{l}\text { FDA approval } \\
>10 \% \text { incidence }\end{array}$ & $\begin{array}{c}\text { Common } \\
\text { adverse effects }\end{array}$ & $\begin{array}{l}\text { Administration } \\
\text { in pregnancy }\end{array}$ & Contraindications/interactions \\
\hline Atomoxetine & $\begin{array}{l}\text { Approved to treat } \\
\text { attention-deficit/ } \\
\text { hyperactivity } \\
\text { disorder in pediatric } \\
\text { and adult patients }\end{array}$ & $\begin{array}{l}\text { Nausea, xerostomia } \\
\text { (dry mouth), appetite } \\
\text { loss, insomnia, fatigue, } \\
\text { headache and cough }\end{array}$ & $\begin{array}{l}\text { Use during } \\
\text { pregnancy has } \\
\text { not been well } \\
\text { studied for }\end{array}$ & $\begin{array}{l}\text { Hypersensitivity and } \\
\text { Symptomatic cardiovascular } \\
\text { disease. } \\
\text { Treatment with CYP2D6 } \\
\text { inhibitors or inducers, } \\
\text { Antihypertensive and } \\
\text { pressor agents and } \\
\beta \text {-adrenoceptor agonists }\end{array}$ \\
\hline Reboxetine & $\begin{array}{l}\text { Still not fully } \\
\text { approved }\end{array}$ & $\begin{array}{l}\text { Insomnia, nausea, } \\
\text { hyperhidrosis, dry } \\
\text { mouth and } \\
\text { constipation }\end{array}$ & $\begin{array}{l}\text { Only if the } \\
\text { potential benefits } \\
\text { justify the } \\
\text { potential risks } \\
\text { to the fetus }\end{array}$ & $\begin{array}{l}\text { Prostatic hypertrophy, } \\
\text { narrow-angle glaucoma, } \\
\text { epilepsy, CV disease, } \\
\text { bipolar disorder, } \\
\text { MAOIs and urinary } \\
\text { retention. } \\
\text { Markedly inhibited by } \\
\text { papaverine and ketoconazole } \\
\text { (due to inhibition of } \\
\text { CYP3A4). }\end{array}$ \\
\hline Viloxazine & Withdrawn in 2002 & $\begin{array}{l}\text { Nausea, vomiting, } \\
\text { insomnia, loss of } \\
\text { appetite, increased } \\
\text { ESR, EEG anomalies, } \\
\text { vertigo, orthostatic } \\
\text { hypotension, edema } \\
\text { of the lower } \\
\text { extremities, tremor } \\
\text { and mental confusion. }\end{array}$ & $\begin{array}{l}\text { Based on } \\
\text { experimental } \\
\text { studies; maternal } \\
\text { harm when used } \\
\text { during pregnancy }\end{array}$ & $\begin{array}{l}\text { Increased plasma levels of } \\
\text { phenytoin and increased } \\
\text { plasma levels of } \\
\text { theophylline. }\end{array}$ \\
\hline
\end{tabular}

Table VII. Serotonin antagonist and reuptake inhibitors (167).

\begin{tabular}{|c|c|c|c|c|}
\hline Drug & $\begin{array}{c}\text { FDA } \\
\text { approval }\end{array}$ & $\begin{array}{c}\text { Common } \\
\text { adverse effects } \\
>10 \% \text { incidence }\end{array}$ & $\begin{array}{l}\text { Administration } \\
\text { in pregnancy }\end{array}$ & Contraindications/interactions \\
\hline Etoperidone & Discontinued & - & - & - \\
\hline Lubazodone & Discontinued & - & - & - \\
\hline Nefazodone & 2004 & $\begin{array}{l}\text { Dry mouth, sedation/ } \\
\text { somnolence, nausea, } \\
\text { dizziness, blurred/ } \\
\text { abnormal vision, } \\
\text { weakness, lightheadedness, } \\
\text { confusion and orthostatic } \\
\text { hypotension }\end{array}$ & $\begin{array}{l}\text { Not allowed } \\
\text { (category C) }\end{array}$ & $\begin{array}{l}\text { Potent inhibitor for CYP3A4; } \\
\text { interacts with compounds } \\
\text { metabolized by CYP3A4 }\end{array}$ \\
\hline Trazodone & 1981 & $\begin{array}{l}\text { Sedation, orthostatic } \\
\text { hypotension, Cardiac } \\
\text { arrhythmia and Priapism } \\
\text { (rare) }\end{array}$ & $\begin{array}{l}\text { Sufficient data } \\
\text { in humans are } \\
\text { lacking }\end{array}$ & $\begin{array}{l}\text { Increased serum phenytoin } \\
\text { and digoxin levels. Enhance } \\
\text { the sedative effects of } \\
\text { barbiturates, alcohol and } \\
\text { other CNS depressants }\end{array}$ \\
\hline
\end{tabular}


Table VIII. Serotonin-norepinephrine reuptake inhibitors (168).

\begin{tabular}{|c|c|c|c|c|}
\hline Drug & $\begin{array}{c}\text { FDA } \\
\text { approval }\end{array}$ & $\begin{array}{l}\text { Common } \\
\text { adverse effects } \\
>10 \% \text { incidence }\end{array}$ & $\begin{array}{l}\text { Administration } \\
\text { in pregnancy }\end{array}$ & Contraindications/interactions \\
\hline Desvenlafaxine & 2008 & $\begin{array}{l}\text { Insomnia, nausea, headache, } \\
\text { diarrhea, constipation, dry } \\
\text { mouth, dizziness, fatigue and } \\
\text { hyperhidrosis }\end{array}$ & $\begin{array}{l}\text { Only if the potential } \\
\text { benefits justify the } \\
\text { potential risks to } \\
\text { the fetus }\end{array}$ & $\begin{array}{l}\text { Sertraline, aripiprazole, amphetamine, } \\
\text { bupropion, dextroamphetamine, } \\
\text { alprazolam, duloxetine, } \\
\text { Fish Oil, lamotrigine, lurasidone, } \\
\text { lisdexamfetamine, escitalopram, } \\
\text { lithium, pregabalin, acetaminophen, } \\
\text { ascorbic acid, quetiapine, } \\
\text { cyanocobalamin, cholecalciferol and } \\
\text { cetirizine. }\end{array}$ \\
\hline Duloxetine & 2003 & $\begin{array}{l}\text { Nausea, somnolence, } \\
\text { insomnia and dizziness }\end{array}$ & $\begin{array}{l}\text { Increases the risk of } \\
\text { congenital } \\
\text { malformations, } \\
\text { preterm birth, or } \\
\text { pre-eclampsia }\end{array}$ & $\begin{array}{l}\text { Hypersensitivity, CNS acting drugs } \\
\text { with similar mechanism and } \\
\text { thioridazine }\end{array}$ \\
\hline Levomilnacipran & 2013 & $\begin{array}{l}\text { Blood pressure increases, } \\
\text { nausea/vomiting, sweating, } \\
\text { constipation, erectile } \\
\text { dysfunction in men and } \\
\text { increased heart rate }\end{array}$ & $\begin{array}{l}\text { Only if the potential } \\
\text { benefits justify the } \\
\text { potential risks to } \\
\text { the fetus }\end{array}$ & $\begin{array}{l}\text { Aripiprazole, amphetamine, dextro } \\
\text { amphetamine, clonazepam, } \\
\text { duloxetine, gabapenti, clonazeamn, } \\
\text { lamotrigine, pregabalin, metformin, } \\
\text { omeprazole, quetiapine, topiramate, } \\
\text { tramadol and trazodone }\end{array}$ \\
\hline Milnacipran & 2009 & $\begin{array}{l}\text { Tachycardia, palpitations, dry } \\
\text { mouth, hypertension, nausea, } \\
\text { vomiting, headache, insomnia, } \\
\text { dizziness, constipation, } \\
\text { hyperhidrosis and } \\
\text { facial flushing }\end{array}$ & $\begin{array}{l}\text { Not allowed } \\
\text { (category C) }\end{array}$ & $\begin{array}{l}\text { MAOIs (serotonin syndrome), angina } \\
\text { pectoris, myocardial infarction, } \\
\text { epinephrine, norepinephrine, } \\
\text { clonidine, digitalis and triptans and } \\
\text { alcohol }\end{array}$ \\
\hline Venlafaxine & 2006 & $\begin{array}{l}\text { Headache, nausea, dry mouth, } \\
\text { somnolence, asthenia, } \\
\text { dizziness, failure of } \\
\text { ejaculation and sweating. }\end{array}$ & - & Hypersensitive and with MAOI \\
\hline
\end{tabular}

Fortunately, Dexamethasone level has previously been shown to possess a good prognosis for endocrine dysfunction in depression (152).

The United States FDA has approved the use of the antimalarial drugs chloroquine (N4-(7-chloro-4-quinolinyl)N1,N1-diethyl-1,4-pentanediamine) and hydroxychloroquine sulfate (a derivative of chloroquine) in COVID-19 treatment regardless of a questionable clinical proof of their effectiveness (153). Behavioral changes, delirium and depression have been associated with chloroquine use (153). One of the most important points that must be taken into account is the older population, who are directed to self-isolate for a long time. This is to protect over-loaded health systems and to diminish the outbreak of COVID-19. This social isolation not only increases the risk for neurocognitive, cardiovascular and autoimmune diseases but also exposes elder populations to a greater risk of depression (154). Decision makers and leaders need to realize the resultant mental health changes. In addition, they must take the situational depression existing at present into their consideration and give it the care and attention it deserves.

\section{Depression and cytokine storm in COVID-19}

Alteration in consciousness is one of COVID-19 manifestations and accounts for $20 \%$ of patients (155). Furthermore, increased incidence of psychiatric disorders has been identified during and after the infection with COVID-19 (156). Most of these patients display cytokine storm or cytokine release syndrome and showed raised plasma levels of pro-inflammatory cytokines including IL-2R, IL-6, IL-8, IL-10 and TNF- $\alpha$ (157). Depression is known to be an inflammatory state in which the patients manifested high levels of inflammatory cytokines, normalized after anti-depressants treatment (158). In the central nervous system and the peripheral blood, elevated levels of IL-1 $\beta$, IL-6, IL-8, CRP and TNF- $\alpha$ cytokines are identified in patients with depression (159). Blocking of cytokines by IL-1 $\beta$ receptor antagonist, Anakinra or IL-6 
Table IX. Noradrenaline and dopamine reuptake inhibitors (169).

\begin{tabular}{|c|c|c|c|c|}
\hline Drug & $\begin{array}{c}\text { FDA } \\
\text { approval }\end{array}$ & $\begin{array}{c}\text { Common } \\
\text { adverse effects } \\
>10 \% \text { incidence }\end{array}$ & $\begin{array}{l}\text { Administration } \\
\text { in pregnancy }\end{array}$ & Contraindications/interactions \\
\hline Bupropion & 1985 & $\begin{array}{l}\text { Anxiety, restlessness, } \\
\text { dry mouth, } \\
\text { hyperventilation, } \\
\text { irritability, shaking, } \\
\text { irregular heartbeats, } \\
\text { trouble sleeping and } \\
\text { ringing in the ears. }\end{array}$ & $\begin{array}{l}\text { Only if the } \\
\text { potential benefit } \\
\text { outweighs the } \\
\text { potential risk } \\
\text { to the fetus }\end{array}$ & $\begin{array}{l}\text { Epilepsy, conditions that lower } \\
\text { the seizure threshold (anorexia } \\
\text { nervosa, bulimia nervosa, } \\
\text { benzodiazepine or alcohol } \\
\text { withdrawal), MAOIs, liver } \\
\text { damage, kidney disease, } \\
\text { severe hypertension,in } \\
\text { children and adolescents } \\
\text { (risk of suicidal attempt). } \\
\text { Drug-drug interactions: } \\
\text { acetaminophen, } \\
\text { diphenhydramine Drug-food/ } \\
\text { beverage interactions: } \\
\text { grapefruit juice }\end{array}$ \\
\hline
\end{tabular}

receptor antagonist Tocilizumab (160) has benefits on the inflammation-mediated respiratory failure in patients with depression. Based on the previous reports, the present study suggested the protective effect of cytokine blockers against depression symptoms in COVID-19 patients.

\section{Summary}

Treatment of depression remains a great public mental health problem. Depression comprises different types, some of which are related to events in a person's life while others are related to the chemical changes in the brain. In some cases, depression may be considered as a risk factor for certain diseases (e.g. type 1 or 2 diabetes), and in other cases, certain diseases (e.g. Alzheimer's and epilepsy) may lead to depressive episodes. Thus, the relationship between such diseases and depression was discussed in the present study. In addition, the newer treatments of depression, such as modulation of glutamatergic, neuronal NMDA and serotonergic systems and triple reuptake inhibitors, were also presented. The newer treatments result in a lower risk of suicidal attempts compared to older treatments. However, they still have some risks including the possibility of drug abuse. Cooperation between governmental organizations, researchers, clinicians, patients and family is crucial in future progress.

Until now, nothing has been known about the direct effect of COVID-19 on the brain. What health care staff can do is to treat depression resulting from COVID-19 infection and its complications, if there are any. The challenge facing health care staff is to treat the so-called defeat stress resulting from the consequences of COVID-19 infection. Defeat stress consequences may not be able to respond to the classical antidepressants which include maladaptive behaviors $(161,162)$. COVID-19 patients need both pharmacological treatment and mental care. Mental health personnel have to be close to COVID-19 patients directly or indirectly through the internet video media or telephone to soothe or prevent waves depression or low moods. Decision-makers and officials all over the world need to know that emotional or situational depression has to be taken seriously.

\section{Acknowledgements}

Researchers would like to thank the Deanship of Scientific Research, Qassim University for funding the publication of this project.

\section{Funding}

Researchers would like to thank the Deanship of Scientific Research, Qassim University for funding the publication of this project.

\section{Availability of data and materials}

Not applicable.

\section{Authors' contributions}

MSAB conceived, designed, analyzed and presented diagrams, wrote and revised the review. AHA and EA constructed diagrams, wrote and revised the review. TMF wrote and revised the review. Data authentication is not applicable. All authors read and approved the final manuscript.

\section{Ethics approval and consent to participate}

Not applicable.

\section{Patient consent for publication}

Not applicable. 


\section{Competing interests}

The authors declare that they have no competing interests.

\section{References}

1. Averina OV, Zorkina YA, Yunes RA, Kovtun AS, Ushakova VM Morozova AY, Kostyuk GP, Danilenko VN and Chekhonin VP Bacterial metabolites of human gut microbiota correlating with depression. Int J Mol Sci 21: 9234, 2020.

2. Delgado PL and Moreno FA: Role of norepinephrine in depression. J Clin Psychiatry 61 (Suppl 1): S5-S12, 2000.

3. Zhang FF, Peng W, Sweeney JA, Jia ZY and Gong QY: Brain structure alterations in depression: Psychoradiological evidence. CNS Neurosci Ther 24: 994-1003, 2018.

4. Fox ME and Lobo MK: The molecular and cellular mechanisms of depression: A focus on reward circuitry. Mol Psychiatry 24 $1798-1815,2019$

5. Muller JK and Leweke FM: Bipolar disorder: Clinical overview. Med Monatsschr Pharm 39: 363-369, 2016.

6. American Psychiatric Association A and Association AP Diagnostic and Statistical Manual of Mental Dsorders (DSM-5) American Psychiatric Association, Washington, DC, 2013.

7. Assari S: Chronic medical conditions and major depressive disorder: Differential role of positive religious coping among African Americans, Caribbean blacks and non-hispanic whites. Int J Prev Med 5: 405-413, 2014.

8. Devanand DP: Dysthymic disorder in the elderly population. Int Psychogeriatr 26: 39-48, 2014

9. Molyneaux E, Poston L, Ashurst-Williams S and Howard LM: Obesity and mental disorders during pregnancy and postpartum: A systematic review and meta-analysis. Obstet Gynecol 123 857-867, 2014

10. Sanassi LA: Seasonal affective disorder: Is there light at the end of the tunnel? JAAPA 27: 18-23, 2014

11. Gremaud-Heitz D, Riemenschneider A, Walter M, Sollberger D, Kuchenhoff J and Dammann G: Comorbid atypical depression in borderline personality disorder is common and correlated with anxiety-related psychopathology. Compr Psychiatry 55: 650-656, 2014.

12. Østergaard SD, Meyers BS, Flint AJ, Mulsant BH, Whyte EM, Ulbricht CM, Bech P and Rothschild AJ; STOP-PD Study Group: Measuring psychotic depression. Acta Psychiatr Scand 129: 211-220, 2014

13. Muralidharan K, Torres IJ, Silveira LE, Kozicky JM, Bücker J, Fernando $\mathrm{N}$ and Yatham LN: Impact of depressive episodes on cognitive deficits in early bipolar disorder: Data from the systematic treatment optimization programme for early mania (STOP-EM). Br J Psychiatry 205: 36-43, 2014.

14. Benti L, Manicavasagar V, Proudfoot J and Parker G: Identifying early indicators in bipolar disorder: A qualitative study. Psychiatr Q 85: 143-153, 2014.

15. Harnic D, Pompili M, Innamorati M, Erbuto D, Lamis DA, Bria $P$, Girardi P and Janiri L: Affective temperament and attachment in adulthood in patients with bipolar disorder and cyclothymia. Compr Psychiatry 55: 999-1006, 2014.

16. Craner JR, Sigmon ST, Martinson AA and McGillicuddy ML: Premenstrual disorders and rumination. J Clin Psychol 70: 32-47, 2014.

17. Simpson T and Ivey J: Pediatric management problems Situational depression. Pediatr Nurs 31: 312-313, 2005.

18. Jorm AF, Christensen H, Griffiths KM and Rodgers B: Effectiveness of complementary and self-help treatments for depression. Med J Aust 176: S84-S96, 2002.

19. Baldwin DS: Unmet needs in the pharmacological management of depression. Hum Psychopharmacol 16: S93-S99, 2001.

20. Hossain MM, Tasnim S, Sultana A, Faizah F, Mazumder H, Zou L, McKyer ELJ, Ahmed HU and Ma P: Epidemiology of mental health problems in COVID-19: A review. F1000Res 9: 636, 2020.

21. Pedersen CB, Mors O, Bertelsen A, Waltoft BL, Agerbo E, McGrath JJ, Mortensen PB and Eaton WW: A comprehensive nationwide study of the incidence rate and lifetime risk for treated mental disorders. JAMA Psychiatry 71: 573-581, 2014.

22. Mojtabai R, Olfson M and Han B: National trends in the prevalence and treatment of depression in adolescents and young adults. Pediatrics 138: e20161878, 2016.

23. Substance Abuse and Mental Health Services Association, 2018
24. Duffy ME, Twenge JM and Joiner TE: Trends in mood and anxiety symptoms and suicide-related outcomes among U.S. undergraduates, 2007-2018: Evidence from two national surveys. J Adolesc Health 65: 590-598, 2019.

25. Kuehner C: Why is depression more common among women than among men? Lancet Psychiatry 4: 146-158, 2017.

26. Wang PS, Aguilar-Gaxiola S, Alonso J, Angermeyer MC, Borges G, Bromet EJ, Bruffaerts R, de Girolamo G, de Graaf R, Gureje O, et al: Use of mental health services for anxiety, mood, and substance disorders in 17 countries in the WHO world mental health surveys. Lancet 370: 841-850, 2007.

27. Katon W and Sullivan MD: Depression and chronic medical illness. J Clin Psychiatry 51 (Suppl): S3-S14, 1990.

28. Lebowitz BD, Pearson JL, Schneider LS, Reynolds CF III, Alexopoulos GS, Bruce ML, Conwell Y, Katz IR, Meyers BS, Morrison MF, et al: Diagnosis and treatment of depression in late life. Consensus statement update. JAMA 278: 1186-1190, 1997.

29. Slavich GM and Irwin MR: From stress to inflammation and major depressive disorder: A social signal transduction theory of depression. Psychol Bull 140: 774-815, 2014.

30. Green RC, Cupples LA, Kurz A, Auerbach S, Go R, Sadovnick D, Duara R, Kukull WA, Chui H, Edeki T, et al: Depression as a risk factor for Alzheimer disease: The MIRAGE study. Arch Neurol 60: 753-759, 2003

31. Ramasubbu R and Patten SB: Effect of depression on stroke morbidity and mortality. Can J Psychiatry 48: 250-257, 2003.

32. Hesdorffer DC, Hauser WA, Annegers JF and Cascino G: Major depression is a risk factor for seizures in older adults. Ann Neurol 47: 246-249, 2000.

33. Nouwen A, Lloyd CE and Pouwer F: Depression and type 2 diabetes over the lifespan: A meta-analysis. Response to Mezuk et al: Diabetes Care 32: e56-e57, 2009.

34. Penninx BW, Guralnik JM, Pahor M, Ferrucci L, Cerhan JR, Wallace RB and Havlik RJ: Chronically depressed mood and cancer risk in older persons. J Natl Cancer Inst 90: 1888-1893, 1998.

35. Keller MB, Hirschfeld RM, Demyttenaere K and Baldwin DS: Optimizing outcomes in depression: Focus on antidepressant compliance. Int Clin Psychopharmacol 17: 265-271, 2002.

36. Bouwman V, Adriaanse MC, van 't Riet E, Snoek FJ, Dekker JM and Nijpels G: Depression, anxiety and glucose metabolism in the general dutch population: The New Hoorn Study. PLoS One 5: e9971, 2010.

37. Shelton RC and Miller AH: Eating ourselves to death (and despair): The contribution of adiposity and inflammation to depression. Prog Neurobiol 91: 275-299, 2010.

38. Shirey K, Manyara SM, Atwoli L, Tomlin R, Gakinya B, Cheng S, Kamano J, Laktabai J and Pastakia S: Symptoms of depression among patients attending a diabetes care clinic in rural western Kenya. J Clin Transl Endocrinol 2: 51-54, 2015.

39. Häfner S, Baumert J, Emeny RT, Lacruz ME, Thorand B, Herder C, Koenig W, Rupprecht R and Ladwig KH: Sleep disturbances and depressed mood: A harmful combination associated with increased leptin levels in women with normal weight. Biol Psychol 89: 163-169, 2012

40. Becker C, Zeau B, Rivat C, Blugeot A, Hamon M and Benoliel JJ: Repeated social defeat-induced depression-like behavioral and biological alterations in rats: Involvement of cholecystokinin. Mol Psychiatry 13: 1079-1092, 2008.

41. Kozlovsky N, Matar MA, Kaplan Z, Zohar J and Cohen H: The role of the galaninergic system in modulating stress-related responses in an animal model of posttraumatic stress disorder. Biol Psychiatry 65: 383-391, 2009.

42. Cline BH, Steinbusch HW, Malin D, Revishchin AV, Pavlova GV, Cespuglio R and Strekalova T: The neuronal insulin sensitizer dicholine succinate reduces stress-induced depressive traits and memory deficit: Possible role of insulin-like growth factor 2 . BMC Neurosci 13: 110, 2012

43. Roesler R, Henriques JA and Schwartsmann G: Gastrin-releasing peptide receptor as a molecular target for psychiatric and neurological disorders. CNS Neurol Disord Drug Targets 5: 197-204, 2006.

44. Musselman DL and Nemeroff CB: Depression and endocrine disorders: Focus on the thyroid and adrenal system. Br J Psychiatry Suppl: 123-128, 1996.

45. Frey A, Lampert A, Dietz K, Striebich S, Locher C, Fedorenko O, Möhle R, Gallinat J, Lang F and Lang UE: Thyrotropin serum concentrations in healthy volunteers are associated with depression-related personality traits. Neuropsychobiology 56: 123-126, 2007. 
46. Bahls SC and de Carvalho GA: The relation between thyroid function and depression: A review. Braz J Psychiatry 26: 41-49, 2004 (In Portuguese).

47. Cleare AJ, McGregor A and O'Keane V: Neuroendocrine evidence for an association between hypothyroidism, reduced central 5-HT activity and depression. Clin Endocrinol (Oxf) 43 713-719, 1995.

48. Holtzheimer PE III and Nemeroff CB: Future prospects in depression research. Dialogues Clin Neurosci 8: 175-189, 2006.

49. Banki CM, Bissette G, Arato M, O'Connor L and Nemeroff CB: CSF corticotropin-releasing factor-like immunoreactivity in depression and schizophrenia. Am J Psychiatry 144: 873-877, 1987.

50. Lippi G, Montagnana M, Favaloro EJ and Franchini M: Mental depression and cardiovascular disease: A multifaceted, bidirectional association. Semin Thromb Hemost 35: 325-336, 2009.

51. Tiemeier H, van Dijck W, Hofman A, Witteman JC, Stijnen T and Breteler MM: Relationship between atherosclerosis and latelife depression: The rotterdam study. Arch Gen Psychiatry 61: 369-376, 2004

52. Nemeroff CB and Goldschmidt-Clermont PJ: Heartache and heartbreak-the link between depression and cardiovascular disease. Nat Rev Cardiol 9: 526-539, 2012.

53. Geiser F, Meier C, Wegener I, Imbierowicz K, Conrad R, Liedtke R, Oldenburg J and Harbrecht U: Association between anxiety and factors of coagulation and fibrinolysis. Psychother Psychosom 77: 377-383, 2008.

54. Nemeroff CB and Musselman DL: Are platelets the link between depression and ischemic heart disease? Am Heart J 140 (Suppl 4): S57-S62, 2000.

55. Stafford $L$ and Berk M: The use of statins after a cardiac intervention is associated with reduced risk of subsequent depression: Proof of concept for the inflammatory and oxidative hypotheses of depression? J Clin Psychiatry 72: 1229-1235, 2011.

56. Jin K, Zhu Y, Sun Y, Mao XO, Xie L and Greenberg DA: Vascular endothelial growth factor (VEGF) stimulates neurogenesis in vitro and in vivo. Proc Natl Acad Sci USA 99: 11946-11950, 2002

57. Warner-Schmidt JL and Duman RS: VEGF is an essential mediator of the neurogenic and behavioral actions of antidepressants. Proc Natl Acad Sci USA 104: 4647-4652, 2007.

58. Kahl KG, Bens S, Ziegler K, Rudolf S, Kordon A, Dibbelt L and Schweiger U: Angiogenic factors in patients with current major depressive disorder comorbid with borderline personality disorder. Psychoneuroendocrinology 34: 353-357, 2009.

59. Nakataki M, Iga J, Numata S, Yoshimoto E, Kodera K, Watanabe SY, Song H, Ueno S and Ohmori T: Gene expression and association analysis of the epithelial membrane protein 1 gene in major depressive disorder in the Japanese population. Neurosci Lett 489: 126-130, 2011.

60. Dantzer R: Cytokine, sickness behavior, and depression Immunol Allergy Clin North Am 29: 247-264, 2009.

61. Akhondzadeh S, Jafari S, Raisi F, Nasehi AA, Ghoreishi A, Salehi B, Mohebbi-Rasa S, Raznahan M and Kamalipour A Clinical trial of adjunctive celecoxib treatment in patients with major depression: A double blind and placebo controlled trial. Depress Anxiety 26: 607-611, 2009.

62. Müller N, Schwarz MJ, Dehning S, Douhe A, Cerovecki A, Goldstein-Müller B, Spellmann I, Hetzel G, Maino K, Kleindienst $N$, et al: The cyclooxygenase-2 inhibitor celecoxib has therapeutic effects in major depression: Results of a double-blind, randomized, placebo controlled, add-on pilot study to reboxetine. Mol Psychiatry 11: 680-684, 2006.

63. Nery FG, Monkul ES, Hatch JP, Fonseca M, Zunta-Soares GB, Frey BN, Bowden CL and Soares JC: Celecoxib as an adjunct in the treatment of depressive or mixed episodes of bipolar disorder: A double-blind, randomized, placebo-controlled study. Hum Psychopharmacol 23: 87-94, 2008.

64. Kumar B, Kuhad A and Chopra K: Neuropsychopharmacological effect of sesamol in unpredictable chronic mild stress mode of depression: Behavioral and biochemical evidences. Psychopharmacology (Berl) 214: 819-828, 2011.

65. Lau BW, Ren C, Yang J, Yan SW, Chang RC, Pu M and So KF: Light deprivation induces depression-like behavior and suppresses neurogenesis in diurnal mongolian gerbil (Meriones unguiculatus). Cell Transplant 20: 871-881, 2011.

66. Ljubicić D, Stipcević T, Pivac N, Jakovljević M and MückSeler D: The influence of daylight exposure on platelet 5-HT levels in patients with major depression and schizophrenia. J Photochem Photobiol B 89: 63-69, 2007.
67. Ubbenhorst A, Striebich S, Lang F and Lang UE: Exploring the relationship between vitamin $\mathrm{D}$ and basic personality traits. Psychopharmacology (Berl) 215: 733-737, 2011.

68. LeBourgeois MK, Carskadon MA, Akacem LD, Simpkin CT, Wright KP Jr, Achermann P and Jenni OG: Circadian phase and its relationship to nighttime sleep in toddlers. J Biol Rhythms 28: 322-331, 2013.

69. Almeida OP, Marsh K, Alfonso H, Flicker L, Davis TM and Hankey GJ: B-vitamins reduce the long-term risk of depression after stroke: The VITATOPS-DEP trial. Ann Neurol 68: 503-510, 2010.

70. Sanhueza C, Ryan L and Foxcroft DR: Diet and the risk of unipolar depression in adults: Systematic review of cohort studies. J Hum Nutr Diet 26: 56-70, 2013.

71. Lazarou $C$ and Kouta $C$ : The role of nurses in the prevention and management of obesity. Br J Nurs 19: 641-647, 2010.

72. Papakostas GI, Mischoulon D, Shyu I, Alpert JE and Fava M: S-adenosyl methionine (SAMe) augmentation of serotonin reuptake inhibitors for antidepressant nonresponders with major depressive disorder: A double-blind, randomized clinical trial. Am J Psychiatry 167: 942-948, 2010.

73. O'Shea RD: Roles and regulation of glutamate transporters in the central nervous system. Clin Exp Pharmacol Physiol 29: 10181023, 2002.

74. Erecińska M and Silver IA: Metabolism and role of glutamate in mammalian brain. Prog Neurobiol 35: 245-296, 1990.

75. Banasr M, Chowdhury GM, Terwilliger R, Newton SS, Duman RS, Behar KL and Sanacora G: Glial pathology in an animal model of depression: Reversal of stress-induced cellular, metabolic and behavioral deficits by the glutamate-modulating drug riluzole. Mol Psychiatry 15: 501-511, 2010.

76. Gourley SL, Espitia JW, Sanacora G and Taylor JR: Antidepressant-like properties of oral riluzole and utility of incentive disengagement models of depression in mice. Psychopharmacology (Berl) 219: 805-814, 2012.

77. Diazgranados N, Ibrahim L, Brutsche NE, Newberg A, Kronstein P, Khalife S, Kammerer WA, Quezado Z, Luckenbaugh DA, Salvadore G, et al: A randomized add-on trial of an N-methyl-D-aspartate antagonist in treatment-resistant bipolar depression. Arch Gen Psychiatry 67: 793-802, 2010.

78. Lauterbach EC: Dextromethorphan as a potential rapid-acting antidepressant. Med Hypotheses 76: 717-719, 2011.

79. Drevets WC and Furey ML: Replication of scopolamine's antidepressant efficacy in major depressive disorder: A randomized, placebo-controlled clinical trial. Biol Psychiatry 67: 432-438, 2010.

80. Furey ML and Drevets WC: Antidepressant efficacy of the antimuscarinic drug scopolamine: A randomized, placebo-controlled clinical trial. Arch Gen Psychiatry 63: 1121-1129, 2006.

81. Sawada T and Yokoi K: Effect of zinc supplementation on mood states in young women: A pilot study. Eur J Clin Nutr 64: 331-333, 2010.

82. Barragán-Rodríguez L， Rodríguez-Morán $M$ and Guerrero-Romero F: Efficacy and safety of oral magnesium supplementation in the treatment of depression in the elderly with type 2 diabetes: A randomized, equivalent trial. Magnes Res 21: 218-223, 2008

83. Schmidt HD and Duman RS: The role of neurotrophic factors in adult hippocampal neurogenesis, antidepressant treatments and animal models of depressive-like behavior. Behav Pharmacol 18: 391-418, 2007.

84. Schmidt HD, Shelton RC and Duman RS: Functional biomarkers of depression: Diagnosis, treatment, and pathophysiology. Neuropsychopharmacology 36: 2375-2394, 2011.

85. PittengerCand Duman RS: Stress, depression, and neuroplasticity: A convergence of mechanisms. Neuropsychopharmacology 33: 88-109, 2008

86. Schinder AF and Poo M: The neurotrophin hypothesis for synaptic plasticity. Trends Neurosci 23: 639-645, 2000.

87. Aydemir O, Deveci A and Taneli F: The effect of chronic antidepressant treatment on serum brain-derived neurotrophic factor levels in depressed patients: A preliminary study. Prog Neuropsychopharmacol Biol Psychiatry 29: 261-265, 2005.

88. Sen S, Duman R and Sanacora G: Serum brain-derived neurotrophic factor, depression, and antidepressant medications: Meta-analyses and implications. Biol Psychiatry 64: 527-532, 2008.

89. Cattaneo A, Sesta A, Calabrese F, Nielsen G, Riva MA and Gennarelli M: The expression of VGF is reduced in leukocytes of depressed patients and it is restored by effective antidepressant treatment. Neuropsychopharmacology 35: 1423-1428, 2010. 
90.Hunsberger JG, Newton SS, Bennett AH, Duman $\mathrm{CH}$ Russell DS, Salton SR and Duman RS: Antidepressant actions of the exercise-regulated gene VGF. Nat Med 13: 1476-1482, 2007.

91. Hellweg R, Lang UE, Nagel M and Baumgartner A: Subchronic treatment with lithium increases nerve growth factor content in distinct brain regions of adult rats. Mol Psychiatry 7: 604-608 2002.

92. von Richthofen S, Lang UE and Hellweg R: Effects of different kinds of acute stress on nerve growth factor content in rat brain. Brain Res 987: 207-213, 2003.

93. Rosa AR, Frey BN, Andreazza AC, Ceresér KM, Cunha AB Quevedo J, Santin A, Gottfried C, Gonçalves CA, Vieta E and Kapczinski F: Increased serum glial cell line-derived neurotrophic factor immunocontent during manic and depressive episodes in individuals with bipolar disorder. Neurosci Lett 407 146-150, 2006.

94. Scapagnini G, Davinelli S, Drago F, De Lorenzo A and Oriani G: Antioxidants as antidepressants: Fact or fiction? CNS Drugs 26 477-490, 2012.

95. Leonard B and Maes M: Mechanistic explanations how cellmediated immune activation, inflammation and oxidative and nitrosative stress pathways and their sequels and concomitants play a role in the pathophysiology of unipolar depression. Neurosci Biobehav Rev 36: 764-785, 2012.

96.Lopresti AL, Hood SD and Drummond PD: A review of lifestyle factors that contribute to important pathways associated with major depression: Diet, sleep and exercise. J Affect Disord 148 $12-27,2013$

97. Galecki P: Oxidative stress in depression. In: Systems Biology of Free Radicals and Antioxidants. Laher I (eds). Springer, Berlin, pp2369-2395, 2014.

98.Lukic I, Mitic M, Djordjevic J, Tatalovic N, Bozovic N, Soldatovic I, Mihaljevic M, Pavlovic Z, Radojcic MB, Maric NP and Adzic M: Lymphocyte levels of redox-sensitive transcription factors and antioxidative enzymes as indicators of pro-oxidative state in depressive patients. Neuropsychobiology 70: 1-9, 2014

99. Maes M, Galecki P, Chang YS and Berk M: A review on the oxidative and nitrosative stress (O\&NS) pathways in major depression and their possible contribution to the (neuro)degenerative processes in that illness. Prog Neuropsychopharmaco Biol Psychiatry 35: 676-692, 2011.

100. Halliwell B: Free radicals and antioxidants-quo vadis? Trends Pharmacol Sci 32: 125-130, 2011.

101. Sperner-Unterweger B, Kohl C and Fuchs D: Immune changes and neurotransmitters: Possible interactions in depression? Prog Neuropsychopharmacol Biol Psychiatry 48: 268-276, 2014.

102. Kudlow P, Cha DS, Carvalho AF and McIntyre RS: Nitric oxide and major depressive disorder: Pathophysiology and treatment implications. Curr Mol Med 16: 206-215, 2016.

103. Steinert JR, Chernova T and Forsythe ID: Nitric oxide signaling in brain function, dysfunction, and dementia. Neuroscientist 16 : 435-452, 2010

104. Tobe EH: Mitochondrial dysfunction, oxidative stress, and major depressive disorder. Neuropsychiatr Dis Treat 9: 567-573, 2013.

105. Gandal MJ, Haney JR, Parikshak NN, Leppa V, Ramaswami G Hartl C, Schork AJ, Appadurai V, Buil A, Werge TM, et al: Shared molecular neuropathology across major psychiatric disorders parallels polygenic overlap. Focus (Am Psychiatr Publ) 17: 66-72, 2019.

106. Gandal MJ, Haney JR, Parikshak NN, Leppa V, Ramaswami G, Hartl C, Schork AJ, Appadurai V, Buil A, Werge TM, et al: Shared molecular neuropathology across major psychiatric disorders parallels polygenic overlap. Science 359: 693-697, 2018.

107. Dean B: Understanding the role of inflammatory-related pathways in the pathophysiology and treatment of psychiatric disorders: Evidence from human peripheral studies and CNS studies. Int J Neuropsychopharmacol 14: 997-1012, 2011

108. Akula N, Barb J, Jiang X, Wendland JR, Choi KH, Sen SK, Hou L, Chen DT, Laje G, Johnson K, et al: RNA-sequencing of the brain transcriptome implicates dysregulation of neuroplasticity, circadian rhythms and GTPase binding in bipolar disorder Mol Psychiatry 19: 1179-1185, 2014.

109. Zhao Z, Xu J, Chen J, Kim S, Reimers M, Bacanu SA, Yu H, Liu C, Sun J, Wang Q, et al: Transcriptome sequencing and genome-wide association analyses reveal lysosomal function and actin cytoskeleton remodeling in schizophrenia and bipolar disorder. Mol Psychiatry 20: 563-572, 2015.
110. Bernard R, Kerman IA, Thompson RC, Jones EG, Bunney WE, Barchas JD, Schatzberg AF, Myers RM, Akil $\mathrm{H}$ and Watson SJ: Altered expression of glutamate signaling, growth factor, and glia genes in the locus coeruleus of patients with major depression. Mol Psychiatry 16: 634-646, 2011.

111. Feyissa AM, Chandran A, Stockmeier CA and Karolewicz B: Reduced levels of NR2A and NR2B subunits of NMDA receptor and PSD-95 in the prefrontal cortex in major depression. Prog Neuropsychopharmacol Biol Psychiatry 33: 70-75, 2009.

112. Kang HJ, Adams DH, Simen A, Simen BB, Rajkowska G, Stockmeier CA, Overholser JC, Meltzer HY, Jurjus GJ, Konick LC, et al: Gene expression profiling in postmortem prefrontal cortex of major depressive disorder. J Neurosci 27 13329-13340, 2007.

113. Labonté B, Engmann O, Purushothaman I, Menard C, Wang J, Tan C, Scarpa JR, Moy G, Loh YE, Cahill M, et al: Sex-specific transcriptional signatures in human depression. Nat Med 23: 1102-1111, 2017.

114. Ando V, Claridge G and Clark K: Psychotic traits in comedians. Br J Psychiatry 204: 341-345, 2014.

115. Heyman E, Gamelin FX, Goekint M, Piscitelli F, Roelands B, Leclair E, Di Marzo V and Meeusen R: Intense exercise increases circulating endocannabinoid and BDNF levels in humans-possible implications for reward and depression. Psychoneuroendocrinology 37: 844-851, 2012.

116. Blanke U and te Wildt B: Depressive disorders in the context of biographical and historical changes-experiences within a psychiatric outpatient service. Psychiatr Prax 34 (Suppl 3): S269-S272, 2007 (In German).

117. Wang SJ and Chen MY: The effects of sunlight exposure therapy on the improvement of depression and quality of life in post-stroke patients: A RCT study. Heliyon 6: e04379, 2020.

118. Bouron A and Lorrain E: Cellular and molecular effects of the antidepressant hyperforin on brain cells: Review of the literature. Encephale 40: 108-113, 2014 (In French).

119. Owens MJ, Morgan WN, Plott SJ and Nemeroff CB: Neurotransmitter receptor and transporter binding profile of antidepressants and their metabolites. J Pharmacol Exp Ther 283: 1305-1322, 1997

120. Menkes D, Bosanac P and Castle D: MAOIs-does the evidence warrant their resurrection? Australas Psychiatry 24: 371-373, 2016.

121. Dale E, Bang-Andersen B and Sánchez C: Emerging mechanisms and treatments for depression beyond SSRIs and SNRIs. Biochem Pharmacol 95: 81-97, 2015.

122. Sharma H, Santra S and Dutta A: Triple reuptake inhibitors as potential next-generation antidepressants: A new hope? Future Med Chem 7: 2385-2406, 2015.

123. Cipriani A, Koesters M, Furukawa TA, Nosè M, Purgato M, Omori IM, Trespidi C and Barbui C: Duloxetine versus other anti-depressive agents for depression. Cochrane Database Syst Rev 10: CD006533, 2012.

124. Parker L, Huelin R, Khankhel Z, Wasiak R and Mould J: A systematic review of pharmacoeconomic studies for pregabalin. Pain Pract 15: 82-94, 2015

125. Wu Y, Huang Y, Song M, Zhang Z, Liang Z and Deng X: Anticonvulsive activity of duloxetine: A new choice for the epileptic patients with depression. Pak J Pharm Sci 32: 997-1003, 2019.

126. Kumar R, Sinha VR, Dahiya L and Sarwal A: Transdermal delivery of duloxetine-sulfobutylether- $\beta$-cyclodextrin complex for effective management of depression. Int J Pharm 594: 120129, 2021

127. Ashby CR Jr, Kehne JH, Bartoszyk GD, Renda MJ, Athanasiou M, Pierz KA and Seyfried CA: Electrophysiological evidence for rapid 5-HT1A autoreceptor inhibition by vilazodone, a 5-HT1A receptor partial agonist and 5-HT reuptake inhibitor. Eur J Pharmacol 714: 359-365, 2013.

128. Bathla M and Anjum S: A 12-week prospective randomized controlled comparative trial of vilazodone and sertraline in Indian patients with depression. Indian J Pharmacol 52: 10-15, 2020.

129. Hashimoto K, Malchow B, Falkai P and Schmitt A: Glutamate modulators as potential therapeutic drugs in schizophrenia and affective disorders. Eur Arch Psychiatry Clin Neurosci 263: 367-377, 2013

130. Burgdorf J, Zhang XL, Weiss C, Matthews E, Disterhoft JF, Stanton PK and Moskal JR: The N-methyl-D-aspartate receptor modulator GLYX-13 enhances learning and memory, in young adult and learning impaired aging rats. Neurobiol Aging 32: 698-706, 2011 
131. Mørk A, Montezinho LP, Miller S, Trippodi-Murphy C, Plath N, Li Y, Gulinello M and Sanchez C: Vortioxetine (Lu AA21004), a novel multimodal antidepressant, enhances memory in rats. Pharmacol Biochem Behav 105: 41-50, 2013.

132. Katona C, Hansen T and Olsen CK: A randomized, doubleblind, placebo-controlled, duloxetine-referenced, fixed-dose study comparing the efficacy and safety of Lu AA21004 in elderly patients with major depressive disorder. Int Clin Psychopharmacol 27: 215-223, 2012

133. Xiao L: Agomelatine for postpartum depression and breastfeeding. Ther Adv Psychopharmacol 11: 20451253211022172, 2021

134. de Bodinat C, Guardiola-Lemaitre B, Mocaër E, Renard P, Muñoz C and Millan MJ: Agomelatine, the first melatonergic antidepressant: Discovery, characterization and development. Nat Rev Drug Discov 9: 628-642, 2010.

135. Gumuslu E, Mutlu O, Sunnetci D, Ulak G, Celikyurt IK, Cine N, Akar F, Savlı H and Erden F: The antidepressant agomelatine improves memory deterioration and upregulates CREB and BDNF gene expression levels in unpredictable chronic mild stress (UCMS)-exposed mice. Drug Target Insights 8: 11-21, 2014.

136. Diamond PR, Farmery AD, Atkinson S, Haldar J, Williams N, Cowen PJ, Geddes JR and McShane R: Ketamine infusions for treatment resistant depression: A series of 28 patients treated weekly or twice weekly in an ECT clinic. J Psychopharmacol 28: 536-544, 2014.

137. Aguilar-Valles A, De Gregorio D, Matta-Camacho E, Eslamizade MJ, Khlaifia A, Skaleka A, Lopez-Canul M, Torres-Berrio A, Bermudez S, Rurak GM, et al: Antidepressant actions of ketamine engage cell-specific translation via eIF4E. Nature 590: 315-319, 2021 .

138. Corriger A and Pickering G: Ketamine and depression: A narrative review. Drug Des Devel Ther 13: 3051-3067, 2019.

139. Palmer EC, Binns LN and Carey H: Levomilnacipran: A new serotonin-norepinephrine reuptake inhibitor for the treatment of major depressive disorder. Ann Pharmacother 48: 1030-1039, 2014.

140. Krause-Sorio B, Kilpatrick L, Siddarth P, Ercoli L, Laird KT, Aguilar-Faustino Y, Milillo MM, Narr KL and Lavretsky H: Cortical thickness increases with levomilnacipran treatment in a pilot randomised double-blind placebo-controlled trial in latelife depression. Psychogeriatrics 20: 140-148, 2020.

141. Anthonis E and Sienaert P: Farmacotherapeutic treatment of psychotic depression: A review. Tijdschr Psychiatr 63: 358-365, 2021 (In Dutch).

142. Greer TL, Grannemann BD, Chansard M, Karim AI and Trivedi MH: Dose-dependent changes in cognitive function with exercise augmentation for major depression: Results from the TREAD study. Eur Neuropsychopharmacol 25: 248-256, 2015.

143. Reutfors J, Brenner P, Brody B, Wray H, Andersen M and Brandt L: A post-authorization safety study of quetiapine as antidepressant treatment in Sweden: Nested case-control analyses of select outcomes. Drug Saf 43: 135-145, 2020

144. Torales J, O'Higgins M, Castaldelli-Maia JM and Ventriglio A: The outbreak of COVID-19 coronavirus and its impact on global mental health. Int J Soc Psychiatry 66: 317-320, 2020.

145. Sensoy B, Gunes A and Ari S: Anxiety and depression levels in Covid-19 disease and their relation to hypertension. Clin Exp Hypertens 43: 237-241, 2021.

146. Lai J, Ma S, Wang Y, Cai Z, Hu J, Wei N, Wu J, Du H, Chen T, $\mathrm{Li} \mathrm{R}$, et al: Factors associated with mental health outcomes among health care workers exposed to coronavirus disease 2019. JAMA Netw Open 3: e203976, 2020.

147. Mahalakshmi AM, Ray B, Tuladhar S, Bhat A, Paneyala S, Patteswari D, Sakharkar MK, Hamdan H, Ojcius DM, Bolla SR, et al: Does COVID-19 contribute to development of neurological disease? Immun Inflamm Dis 9: 48-58, 2021.

148. Combe B, Balsa A, Sarzi-Puttini P, Tony HP, de la Torre I, Rogai V, Durand F, Witt S, Zhong J and Dougados M: Efficacy and safety data based on historical or pre-existing conditions at baseline for patients with active rheumatoid arthritis who were treated with baricitinib. Ann Rheum Dis 78: 1135-1138, 2019.

149. Lipworth B, Kuo CR and Chan R: Emerging pharmacotherapy for COVID-19. J R Coll Physicians Edinb 50: 133-137, 2020.

150. Reder AT, Oger JF, Kappos L, O'Connor P and Rametta M: Shortterm and long-term safety and tolerability of interferon $\beta-1 \mathrm{~b}$ in multiple sclerosis. Mult Scler Relat Disord 3: 294-302, 2014.
151. Theoharides TC and Conti P: Dexamethasone for COVID-19? Not so fast. J Biol Regul Homeost Agents 34: 1241-1243, 2020.

152. Menke A, Arloth J, Best J, Namendorf C, Gerlach T, Czamara D, Lucae S, Dunlop BW, Crowe TM, Garlow SJ, et al: Time-dependent effects of dexamethasone plasma concentrations on glucocorticoid receptor challenge tests. Psychoneuroendocrinology 69: 161-171, 2016.

153. Shader RI: COVID-19 and depression. Clin Ther 42: 962-963, 2020.

154. Armitage R and Nellums LB: COVID-19 and the consequences of isolating the elderly. Lancet Public Health 5: e256, 2020.

155. Kumar S, Veldhuis A and Malhotra T: Neuropsychiatric and cognitive sequelae of COVID-19. Front Psychol 12: 577529, 2021.

156. Rogers JP, Chesney E, Oliver D, Pollak TA, McGuire P, FusarPoli P, Zandi MS, Lewis G and David AS: Psychiatric and neuropsychiatric presentations associated with severe coronavirus infections: A systematic review and meta-analysis with comparison to the COVID-19 pandemic. Lancet Psychiatry 7: 611-627, 2020

157. Liu J, Li S, Liu J, Liang B, Wang X, Wang H, Li W, Tong Q, Yi J, Zhao L, et al: Longitudinal characteristics of lymphocyte responses and cytokine profiles in the peripheral blood of SARS-CoV-2 infected patients. EBioMedicine 55: 102763, 2020.

158. Tsamakis K, Mueller C, Tsirigotis P, Tsiptsios D, Tsamakis C, Charakopoulos E, Charalampous C, Spandidos DA, Douzenis A, Papageorgiou C, et al: Depression following graft-versus-host disease in a patient with acute lymphoblastic leukaemia: A case report. Mol Clin Oncol 12: 208-211, 2020.

159. Cavalli G, De Luca G, Campochiaro C, Della-Torre E, Ripa M, Canetti D, Oltolini C, Castiglioni B, Tassan Din C, Boffini N, et al: Interleukin-1 blockade with high-dose anakinra in patients with COVID-19, acute respiratory distress syndrome, and hyperinflammation: A retrospective cohort study. Lancet Rheumatol 2: e325-e331, 2020.

160. Campochiaro C, Della-Torre E, Cavalli G, De Luca G, Ripa M, Boffini N, Tomelleri A, Baldissera E, Rovere-Querini P, Ruggeri A, et al: Efficacy and safety of tocilizumab in severe COVID-19 patients: A single-centre retrospective cohort study. Eur J Intern Med 76: 43-49, 2020

161. Gonda X, Pompili M, Serafini G, Carvalho AF, Rihmer Z and Dome P: The role of cognitive dysfunction in the symptoms and remission from depression. Ann Gen Psychiatry 14: 27, 2015.

162. Martin V, Allaïli N, Euvrard M, Marday T, Riffaud A, Franc B, Mocaër E, Gabriel C, Fossati P, Lehericy S and Lanfumey L: Effect of agomelatine on memory deficits and hippocampal gene expression induced by chronic social defeat stress in mice. Sci Rep 8: 45907, 2017.

163. Yamada M and Yasuhara H: Clinical pharmacology of MAO inhibitors: Safety and future. Neurotoxicology 25: 215-221, 2004.

164. Andrade C: Selective serotonin reuptake inhibitor drug interactions in patients receiving statins. J Clin Psychiatry 75: e95-e99, 2014.

165. Voican CS, Corruble E, Naveau S and Perlemuter G: Antidepressant-induced liver injury: A review for clinicians. Am J Psychiatry 171: 404-415, 2014.

166. Nelson JC: A review of the efficacy of serotonergic and noradrenergic reuptake inhibitors for treatment of major depression. Biol Psychiatry 46: 1301-1308, 1999.

167. Fagiolini A, Comandini A, Catena Dell'Osso M and Kasper S: Rediscovering trazodone for the treatment of major depressive disorder. CNS Drugs 26: 1033-1049, 2012.

168. Jensen NH, Rodriguiz RM, Caron MG, Wetsel WC, Rothman RB and Roth BL: N-desalkylquetiapine, a potent norepinephrine reuptake inhibitor and partial 5-HT1A agonist, as a putative mediator of quetiapine's antidepressant activity. Neuropsychopharmacology 33: 2303-2312, 2008.

169. Ketter TA, Jenkins JB, Schroeder DH, Pazzaglia PJ, Marangell LB, George MS, Callahan AM, Hinton ML, Chao J and Post RM: Carbamazepine but not valproate induces bupropion metabolism. J Clin Psychopharmacol 15: 327-333, 1995.

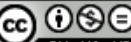

This work is licensed under a Creative Commons Attribution-NonCommercial-NoDerivatives 4.0 International (CC BY-NC-ND 4.0) License. 